\title{
CRENOS
}

PAST DOMINATIONS, CURRENT INSTITUTIONS AND

ITALIAN REGIONAL ECONOMIC PERFORMANCE

Adriana Di Liberto

Marco Sideri

\section{WORKING PAPERS}

$2011 / 15$

$\theta_{\text {CUEC }}$ 


\title{
CEntro Ricerche ECONOMICHE NORd SUd (CRENOS) \\ UNIVERSITÀ DI CAGLIARI \\ UNIVERSITÀ DI SASSARI
}

\begin{abstract}
CRENOS was set up in 1993 with the purpose of organising the joint research effort of economists from the two Sardinian universities (Cagliari and Sassari) investigating dualism at the international and regional level. CRENoS' primary aim is to improve knowledge on the economic gap between areas and to provide useful information for policy intervention. Particular attention is paid to the role of institutions, technological progress and diffusion of innovation in the process of convergence or divergence between economic areas. To carry out its research, CRENoS collaborates with research centres and universities at both national and international level. The centre is also active in the field of scientific dissemination, organizing conferences and workshops along with other activities such as seminars and summer schools.

CRENoS creates and manages several databases of various socio-economic variables on Italy and Sardinia. At the local level, CRENos promotes and participates to projects impacting on the most relevant issues in the Sardinian economy, such as tourism, environment, transports and macroeconomic forecasts.
\end{abstract}

www.crenos.it

info@crenos.it

CRENOS - CAGLIARI

VIA SAN GIORGIO 12, I.09100 CAGLIARI, ITALIA TEL. +39.070.6756406; FAX +39.070.6756402

CRENOS - SASSARI

VIA TORRE TONDA 34, I.07100 SASSARI, ITALIA TEL. + 39.079.2017301; FAX +39.079.2017312

TitIE: PAST DOMINATIONS, CURRENT INSTITUTIONS AND ITALIAN REGIONAL ECONOMIC PERFORMANCE

ISBN: 9788884676795

First Edition: September 2011

Second Edition: February 2012

(c) CUEC 2011

Via Is Mirrionis, 1

$09123 \mathrm{C}$ a g liari

Te $1 . /$ F a x 070291201

ww w. cuec.it 


\title{
Past dominations, current institutions and the Italian regional economic performance
}

\author{
Adriana Di Liberto ${ }^{*}$ Marco Sideri* \\ University of Cagliari and CRENoS
}

\begin{abstract}
We study the connection between economic performance and the quality of government institutions for the sample of 103 Italian NUTS3 regions, including new measures of institutional quality calculated using data on the provision of four areas of public service: health, educational infrastructures, environment and energy. In order to address likely endogeneity problems, we use the histories of the different foreign dominations that ruled Italian regions between the $16^{\text {th }}$ and $17^{\text {th }}$ century and over seven hundred years before the creation of the unified Italian State. Our results suggest a significant role of past historical institutions on the current public administration efficiency and show that the latter makes a difference to the economic performance of regions. Overall, our analysis confirms that informal institutions matter for development, and that history can be used to find suitable instruments.
\end{abstract}

Keywords: economic development, informal institutions, history.

Jel Classifications: O11, O43, C26.

The research leading to these results has received funding from the European Union's Seventh Framework Programme FP7-SSH-2010-2.2-1 (2011-2014), under grant agreement $\mathrm{n}^{\circ} 266834$ SEARCH project. We would like to thank Fabiano Schivardi for his suggestions and Pierpaolo Merlin and Giangiacomo Ortu for very useful discussions on historical facts. We also thank Marco Caliendo, Wendy Carlin, Luigi Guiso, Giovanni Sulis and seminar participants at the 2011 ERSA Conference for their helpful comments and Cristina Murroni and Andrea Schirru for their precious help.

- Address for correspondence: Adriana Di Liberto, DRES, Dipartimento di Ricerche Economiche e Sociali, Facoltà di Scienze Politiche, Università di Cagliari, Viale S. Ignazio 78, 09100 CAGLIARI, Italy. Tel.+070 6753765, Fax +070 6753760. E-mail: diliberto@unica.it.

*E-mail: marco.sideri@crenos.unica.it. 


\section{Introduction}

In this paper we investigate if the efficiency of the public sector has a significant role in the economic development of the Italian regions. To this aim, we first assess the existence of large differences in the performances of local institutions in providing public goods. Second, we identify in the different realms and foreign dominations that ruled the Italian peninsula in the past centuries a crucial factor which helps explain current institutional efficiency. Our analysis is related to the growing literature that dates back to the end of the nineties and investigates how history (and historical institutions) may still influence existing institutions and, only through this channel, current economic outcomes. Seminal contributions in this area are those by Engerman \& Sokoloff (1997, 2002), Acemoglu et al. $(2001,2002)$ and La Porta et al. (1999, 2008). In this framework, good/bad institutions or, more broadly, social infrastructures, characterized by different levels of efficiency and effectiveness, have a fundamental effect on the observed differences in productivity or per capita GDP. ${ }^{1}$

Italian data are most suitable for studying the role that the quality of institutions (broadly defined) have in economic development. First, Italian regions have, with few exceptions, formally identical central Government institutions since 1861. Second, in spite of this apparent institutional homogeneity and unlike most within-country data sets, there exists a deep, persistent duality in the Italian economy between the developed North-Centre and the less developed. Finally, while the dual character of the Italian economy has been often associated to regional differences in fundamentals such as social ${ }^{2}$ and human capital endowments, a satisfying explanation of the persistence of the regional divide has not yet been put forward. ${ }^{3}$ Therefore, the Italian regional data may represent a controlled experiment in ceteris paribus variation of different functioning and effectiveness of local institutions in a developed economy.

${ }^{1}$ For a survey see Nunn (2009) and see also Hall and Jones (1999).

${ }^{2}$ In particular, within the large literature on social capital and development, studies on the Italian regions' case dates back to Banfield (1958) (see also Putnam, 1995), and Italian data still represent one of the most commonly used dataset in these empirical analysis.

${ }^{3}$ On differences in social capital endowments across Italian regions see among the many others the recent papers by Guiso et al. (2008), Tabellini (2010), de Blasio and Nuzzo (2010). On Italian regional dispersion of educational attainments see Di Liberto (2008). 
In defining and testing an explanation based on the role of institutions in economic development, we face two main problems. The first concerns the measurement of institutional quality, the second endogeneity. ${ }^{4}$ To deal with the first problem we calculate different indicators of the efficiency with which local administrations provide public services. The measurement of public sector efficiency is a wellknown difficult empirical issue. Our approach is to calculate the efficiency of public expenditure via composite indicators of public sector performance, defined as the outcome of public policies.

We identify the Italian NUTS3 regions or provinces as the ideal level of geographical disaggregation for an analysis of the role of local institutions. Unlike the regional NUTS2 level of administration, the provision of public services provided by provinces is, at least for the most part, set by the central government, it is very limited in scope and should not involve complex policy decision processes. In particular, provinces are directly involved in the provision of four main areas of public service: environment, health, energy policy and educational infrastructure. Using the data on the public provision of these services we construct five institutional quality indicators, one for each type/area of public service, plus a global indicator based on the sum of the former. A priori, given the strong influence exerted by the central government upon the provision of these public goods at the provincial level, we should expect highly homogeneous efficiency outcomes across different areas. As we shall see shortly, this is not the case. In fact, we observe that the same formal institution seems to function very differently in different environments, suggesting that some location-specific informal factor plays an important role.

To deal with the second concern, the endogeneity problem between economic outcomes and institutional quality, our identification strategy relies on instrumental variables and exploits the Italian past

\footnotetext{
4 While within-country studies are also likely to be plagued by parameter heterogeneity problems that may affect empirical investigations on this topic. As stressed by Eicher and Leukert (2009) empirical cross-country analyses that use both developed and developing countries show parameter heterogeneity problems since it is unclear whether the identified institutions also hold explanatory power in advanced countries and whether they matter to the same degree across all countries or, conversely, a different set of institutions matters in advanced $v s$. developing countries.
} 
history to build different sets of instruments. ${ }^{5}$ Indeed, unlike most European countries, since the Middle Ages the Italian peninsula has been subjected to different waves of colonisations. In general, Italian history has been characterized by high levels of political fragmentation that gave origin to administrations of different kind. The numerous dominators that governed over centuries had very different cultural and political features. Thus, each dominator implemented highly heterogeneous formal institutions in the administrated territories. For instance, the State of the Church was an example of corrupt institutions and administrative inability while, conversely, Austria is usually portrayed as a good administrator that did not implement exploiting or extracting policies. ${ }^{6}$

We focus on the different dominations as the critical historical events that matter for current institutional settings but do not plausibly influence current economic performance. In terms of the empirical strategy, this wide variability among dominators permits the creation of instruments able to capture exogenous variation in regional Italian institutional quality. More precisely, in this study we identify two different candidates and therefore build two different sets of instruments. Our first instruments set uses a series of dummy variables that identify, for each province, the administration that occurred during the period of the Spanish domination in Italy, 1560-1659.This choice is based on two main reasons. First, during this period the Italian peninsula was ruled by different formal governments and each dominance has lasted for a sufficiently long period. Indeed, each province experienced the same formal government for the whole period. Second, Spain has been often portrayed by historians as having negatively affected the dominated areas also through its legacy of inefficient bureaucracy. Our second approach follows a different path with respect to previous studies which are typically based on specific historical events. Instead, here we build a matrix indicating, for each province, the kind and the duration (in years) of domination that ruled during the period between 12th and 18th century. To this aim we collect data for all different

${ }^{5}$ On this see Acemoglu et al. (2001), Rodrick et al. (2004), Pande and Udry (2005), Guiso et al. (2008), Tabellini (2008), Bosker and Garretsen (2009) among the others.

6 "The Habsburg Empire is historically known as a multi-ethnic state with a relatively well functioning, respected bureaucracy". See Becker et al. (2011) p. 2. They investigate if the Habsburg Empire, with its localized and well-respected administration, increased citizens' trust in local public services. 
regimes that governed each Italian province over seven centuries before the creation of the unified Italian State.

In other words, in this study the current functioning of similar formal institutions at the local level are thought to be, at least in part, the result of the previous existence of highly heterogeneous formal institutions created by historical accidents across the Italian regions. In this respect, our study is also related to the recent literature that explores the role in economic outcomes of informal institutions, where the informal element affecting the functioning of similar formal institutions is thought to reflect local differences in social capital, and that in our context is more easily associated with specific features such as managerial practices, culture or citizens behavior (for example, Guiso et al., 2008, and Tabellini, 2010).

Overall, results confirm our expectations. Considering our first stage results, we find that if a province has been dominated by the Papal State it has had a negative impact on institutional quality, while results on the other dominations are less clear-cut, with the Spanish domination coefficient that is, nevertheless, negative and significant in most specifications. Second stage results suggest focusing on our synthetic indicator of public sector efficiency rather than on the four specific areas measures for which outcomes are more fragile and ambiguous. Introducing the former we find that the impact of improving the public sector efficiency of Palermo (the province showing the lowest indicator) to the level of Milan (the highest) is significant and equivalent to a $21 \%$ decrease in the gap between productivity levels measured as added value per worker. That is, we find a significant role of past historical institutions on the current public administration efficiency and, most of all, we confirm that the latter matters for explaining current region's economic performance. Finally, specification tests cast doubts on our second historical matrix approach while, conversely, confirm the first dominations dummies approach.

These results are robust to the inclusion of different additional controls such as human capital and social capital proxies. In particular, our analysis seems to confirm previous evidence that dispute the role of social capital measured by widely used indicators that capture the role of generalized morality and interest in politics, and find that its effect is significantly weakened when a measure of the quality of government institutions is introduced in the analysis. ${ }^{7}$ Finally, we find that public

${ }^{7}$ See Tabellini (2010). 
administration efficiency seems to influence productivity in the most innovative sector, the industrial sector, rather than in agriculture or services.

The structure of this study is based on six different sections. The following section introduces the descriptive analysis, while the third section shows the preliminary OLS results. The empirical strategy and related IV results are described in the fourth section, while the fifth contains our robustness checks. Conclusions are in section six.

\section{Data and measures of institutional quality}

Since the focus of this paper is on the role of the efficiency of institutions on the economic performance of Italian regions we start the analysis by describing how we measure it. Indeed, the quality of institutions is not a variable that we can directly observe and the measurement of public sector efficiency is a well-known difficult empirical issue. In this study we follow an approach that calculates the efficiency of public expenditure via composite indicators of public sector performance, the latter is defined as the outcome of public policies. ${ }^{8}$ These data are provided by the National institute of statistics and, since they are not collected on a regular basis, they relate to years ranging from 1996 to 2002.

We identify the Italian 103 NUTS3 regions or provinces as the ideal level of geographical disaggregation for our analysis of the role of institutional quality. There are two main reasons. First of all, even if provinces have a limited importance in the Italian administrative structure, they are directly involved in the provision of four important areas of public service: ${ }^{?}$

1) Environmental protection;

2) Energy policy;

3) Health system quality:

\footnotetext{
${ }^{8}$ See Afonso et al. (2005). They distinguished between measures of public sector performance, defined as the outcome of public policies, from public sector efficiency, defined as the outcome in relation to the resources employed. Due to data constraint on costs of public services we follow the first approach and identify as a proxy of the quality of institutions different measures of the level of efficiency characterizing certain public services provided by the local governments.

${ }_{9}$ As specifically indicated by the Italian legislation (art. 19 Testo Unico 267/2000 on the local administrations).
} 


\section{4) Educational infrastructure.}

Second, unlike the regional NUTS2 level of administration, the provision of public services provided by provinces is, at least for the most part, set by the central government, it is limited in scope and should not involve complex policy decision processes. Thus, we should expect highly homogeneous efficiency levels across the different areas. ${ }^{10}$ As we shall see, this is not the case: we observe that the same institutions function very differently in different environments, suggesting that informal institutions play an important role. That is, we depart to a certain extent from the vast cross-country literature that examines the role of different formal institutions on economic development. Note that the definitions of formal and informal institutions are the subject of much debate. In particular, the term informal institution encompasses a wide range of concepts; the most intuitive definition of informal institutions is possibly that of 'socially shared unwritten rules' in contrast with the written rules or formal institutions. ${ }^{11}$ Detailed analysis of this issue goes beyond the scope of this research but, as also in Tabellini (2010),we stress that in terms of empirical analysis if informal institutions are important for development we should observe, as we do in our study, different functioning and effectiveness of the same formal institutions.

We focus on the different provisions of public services for the 103 Italian provinces as listed in Italian law and create four different quality of institutions indicators. ${ }^{12}$ These indicators are, in turn, based on 17 different output indicators for the four areas, as listed and described

10 This is not the case at NUTS2 level of disaggregation, since Italian regions have different formal institutional settings (regioni a statuto speciale vs. regioni a statuto ordinario).

${ }^{11}$ "We employ a fourth approach. We define informal institutions as socially shared rules, usually unwritten, that are created, communicated and enforced outside of officially sanctioned channels. By contrast, formal institutions are rules and procedures that are created, communicated, and enforced through channels widely accepted as official." Helmke and Levitsky (2004), p.727. See also Glaeser and Shleifer (2002).

12 See Testo Unico 267/2000.The number and territorial definition of Italian provinces have changed during time but, due to data availability, we follow the administrative structure in force until 2005. NUTS3 regions include between 150 to 800 thousand inhabitants. As an example, the nominal counterpart to a NUTS3 region in a few large countries is County in US, Departements in France and Landkreise in Germany. 
in Appendix A1. As can be seen, these 17 measures take into account different characteristics of the provision of these four public services enabling us to obtain good proxies of institutional quality and efficiency at the finest possible geographical level. ${ }^{13}$ Since we have data with different units of measurement, we use the method of distance and divide each observation by the maximum value displayed by the variable. In this way, we obtain our 17 standardized indicators that show a range between $x_{\min } / x_{\max }$ and 1. Note that, even if the single components are likely to have a different impact and importance we did not find any reference to assign specific weights to each component. Therefore, in constructing our final indicators, in order to avoid arbitrary assignments, we use equal weights and simply sum for each of our four areas of public services the respective standardized components.

Together with these four indicators on environment, energy, health and education we also calculate a synthetic quality of institutions indicator simply representing the sum of the former. We identify this as our key quality or efficiency of institutions indicator. Two main reasons support this choice. First of all, this synthetic measure has the advantage of considering different areas of public service provisions and, for this reasons, it is more likely to affect the overall economic regional performance. Secondly, unlike the four areas indicators, our main efficiency indicator is less likely to be influenced by specific local factors not necessarily related to the efficiency with which the public service is offered. For example, observed regional differences in the provision of Energy services may be influenced by geography while Educational infrastructures and/or the Health indicators by specific local demographic characteristics.

13 A similar approach can be found in Giordano and Tommasino (2011) who calculate different measures of public sector efficiency at Italian provincial level. However, unlike our indicators, their public sector output measures do not satisfy certain characteristics that are important in this setting. First of all, their public sector output measures are provided at different levels of government (Central, regional and provincial). Secondly, they rely on a single and, most of the time, very specific public sector output measures. Finally, they use the DEA approach that is data demanding since it involves the use of public sector input measures as well as output to calculate efficiency. Given the lack of data they need to rely on strong assumptions. We claim that our measures control for most of these potential bias. 
Table 1 shows some descriptive statistics for our five efficiency indicators. For each variable we also report the name of the top/bottom province that shows the highest/lowest value of efficiency. In general, data in part A shows that less efficient regions are mostly located in a specific geographic area, the southern part of the country, while the correlation coefficients reported in part B shows as the synthetic efficiency index is, as expected, highly correlated with the four specific area index, while the latter are not so highly correlated as show values never exceeding 0.5 .

Figures 1 and 2 focus on the territorial distribution of our synthetic indicator. The two-peaks distribution in Figure 2 suggests the presence of two clubs in terms of public sector efficiency, while Figure 1 enables us to geographically identify these clubs. Not surprisingly, the Italian peninsula map in Figure 1 tells us that less efficient areas are mostly located in the South, while the highly efficient club is mainly formed by provinces located in the North and Centre of the country.

We now turn to the analysis of our set of dependent variables. Our main productivity measure is total value added per worker that represents a standard proxy of an area economic performance, but we also use value added of specific sectors, that is, agriculture, industry and services to check if our measure of institutional efficiency differently affects these sectoral performance indicators. These variables are calculated as average value 2002-05. Table 1 introduces some descriptive statistics and shows, not surprisingly, that our various productivity measures are not evenly spread across sectors. In particular, the productivity of the industrial sector has a higher standard deviation value while, as expected, we find the lowest dispersion in the service sector that include both public and private services.

In Figure 3 we investigate how total value added, our main productivity measure, is distributed across Italian provinces: the darker the color in the map, the higher the productivity levels. This map clearly shows the expected significant differences between the Northern provinces and those of Centre and South of Italy. The only exception is given by the province of Rome that exhibits high levels of productivity, a result that is influenced by the presence of the capital city. Areas characterized by high levels of productivity are the Piedmont and the Lombardy, with Milan as leader. Similar characteristics have been also observed when we disaggregate our productivity measure by sectors.

Finally, Figure 4 identifies a clear positive correlation between productivity, measured as per worker total value added, and our main 
measure of institutional quality and shows that, with few exceptions, low levels of efficiency in all areas of public service provision are geographically located in the southern part of the country (the latter identified by red dots, and the remaining provinces by black triangles).

Next, we continue our descriptive analysis with the remaining additional controls. Among the most important in this type of analysis we identify human capital. Indeed, excluding human capital from the analysis would significantly bias our results on the efficiency of institutions indicators as the latter could also capture its effect on per worker value added. As said above, a different value of our quality of institution measures across regions may be the result of bad managerial practices, social norms that encourage shirking, low trust or, more broadly, low social capital. However, all these factors are likely to be highly correlated with low levels of skills in the labor force and population.

Secondly, there is a growing literature that, while stressing the role of educational policies and schooling, seems also to dispute the role of cultural or institutional factors on growth and development. For example, using county-level data from late 19th-century Prussia, Becker et al. (2009) find that, after controlling for the positive effect of literacy on economic success, there remains no significant difference in economic success between Protestant and Catholic counties. Their results seem to invalidate the widespread idea, originated from Max Weber's theories that attributed the higher economic prosperity of Protestant regions to a Protestant work ethic. ${ }^{14}$

Thirdly, unlike most industrialized countries, Italian regions show a high heterogeneity in terms of their human capital endowments, which are considered by a large literature as one of the main determinants of productivity. In general, compulsory schooling was enforced in Italy quite late in the $19^{\text {th }}$ century. Hence, unlike most European countries, Italy stands out as having large regional differences in literacy rates: a significant part of the Italian labor force was totally illiterate, with substantial differences across areas. Using Italian census data in 1971 and 2001 we briefly describe the distribution of human

\footnotetext{
14 On this see also Botticini and Eckstein (2011). They identify in a shift in Jewish religious leadership that required every Jewish man to read and to study the Torah in Hebrew and to send his sons from the age of six or seven to primary school the cause of the following development of institutions that fostered contract enforcement.
} 
capital across Italian provinces. ${ }^{15}$ Table 3 shows the proportion of the population that attained both upper secondary and tertiary education together with data on illiteracy in 1971 and 2001 and average years of education. Data show that tertiary education in Italy in 1971 was achieved by as few as about 2 percent of the population, with no significant differences between North, Centre and South of the country. Conversely, large differences were still present in terms of illiteracy rates. Overall, we observe that, even though Italy has experienced vast increases, from the 1970s onwards, in the average duration of education and even though illiteracy is almost a forgone problem, the country is still plagued by within-country heterogeneity, especially in secondary and tertiary educational attainments. ${ }^{16}$

Using 2001 census data on educational attainment, in our regression analysis we firstly calculate the average years of schooling of the population for each province. ${ }^{17}$ Details are in Appendix A1. Indeed this is a standard measure of the total stock of human capital of an area and represents a better control for human capital than enrolment rates or alternative indicators. With approximately 8 years of education, Caltanisetta and Agrigento (both in Sicily) are the provinces with the lowest educational endowments, while the highest levels are found in Rome, 10.1 years followed by Trieste, 9.9 years.

Among robustness checks we also use a standard measure of social capital as an additional control. The role of social capital in economics is a highly debated issue and this is also certainly due to its "vague and excessively broad definition". ${ }^{18}$ In fact, one of its possible dimensions is measured by our main regressor, that is, the quality of

\footnotetext{
15 The 1971 is the first census in which we have found educational level data at provincial level.

${ }^{16}$ This heterogeneity is also confirmed by human capital quality data. Regional 2009 OCSE-PISA cognitive test results differences goes from 522 (average student's score in reading in Lombardia) to 448 (average student's score in Calabria), approximately the difference observed across countries between the 93 percentile and the 19 percentile (or between Australia and Colombia). See OCSE http://www.pisa.oecd.org/.

${ }^{17}$ Note that we include all regressors measured at some $\mathrm{t}-\tau$ time span with respect to our dependent variables that, as said above, are all measured as average 2002-05. Even if this does not completely solve the problem, this choice enables to better control for likely endogeneity arising from reverse causality. On this see also section 4.

18 See Guiso et al. (2011). On this see also Knack (2002).
} 
governing institutions and the concept of informal institutions and social capital are often used interchangeably. Implications are twofold. First, our efficiency indicators could also capture the effect of alternative social capital dimensions and therefore we need to control for them. For example, social capital may promote institutional effectiveness through its effects on the behavior of bureaucratic elites. It does so through many possible channels since it fosters the ability of bureaucrats to cooperate and work together more efficiently. Secondly, public administrations involve complex institutional arrangements and these organizations are beset by the classic principal/agent problem where senior managers (principals) are responsible for overseeing the work of a very large number of lower-rank administrative personnel (agents). Social capital affects the amount of time and resources principals must devote to monitoring, and with high social capital the organization they control will be more efficient and productive, as the expectations that agents have about the behavior of their colleagues and supervisors are different. ${ }^{19}$

Second, the choice of an additional social capital indicator is not straightforward since one of the main concerns in this empirical literature is also how to measure it. In this paper we use a synthetic social capital index at regional NUTS3 level, provided by Cartocci (2007), which merges data on 1) blood donations, 2) sport participation, 3) dissemination of newspaper and 4) voter turnout. The main advantage of this indicator is that it covers different aspects of social capital. In particular, blood donations data are used to assess the role of "generalized morality", sport participation is assumed to influence social capital since it supports the building of groups of mutual interest and promotes pro-social while diminishing anti-social behavior and, lastly, both newspaper dissemination and voter turnout should capture people's "interest in politics". Table 3 shows a well-known result: synthetic descriptive statistics on our social capital indicator suggests that Italian regions are, as expected, highly heterogeneously endowed. Again, Vibo Valentia and most southern provinces show the lowest values, while, North-Centre provinces (in particular Bologna and Parma are top of the league) have the highest.

19 "As a result, the provision of collective goods will be slower and more expensive than in more civic polities". See Boix and Posner (1998), p. 692. On this see also Ichino and Maggi (2000) who show that prevalence of shirking within large Italian banks can be explained by the effect of peer pressure. 
Finally, we introduce a dummy variable, South, that will assume the value 1 if the province is part of one of the following regions: Abruzzo, Molise, Campania, Basilicata, Puglia, Calabria, Sicily, and Sardinia. There is a large literature showing a clear duality in the Italian economy between the developed North-Centre and the less developed South, suggesting the presence of two convergence clubs. This dummy should thus capture residual and other unobservable geographic or cultural factors that may have independently affected provincial economic performance.

\section{OLS results}

We set the scene with ordinary least squares estimates in order to check the relations between informal institutions and economic outcomes. In particular, we regress our productivity variable of the 103 Italian provinces on our five measures of the efficiency of the public administration, plus a set of control variables:

1) $Y_{i}=\alpha+\beta E F F_{-} I N S T_{i}+X_{i}^{\prime} \gamma+\varepsilon_{i}$

In equation (1) $Y_{i}$ is the outcome variable for province $i$, $E F F_{-} I N S T_{i}$ represents the overall or, alternatively, Environment, Energy, Health, Educational infrastructure public sector efficiency. Finally, $X$ is a vector of covariates that includes a human capital indicator, measured as average years of education, and a dummy variable, South, that assumes value 1 if the province is located in the southern part of the country and zero otherwise, while $\varepsilon_{i}$ represents the error term. Our main coefficient of interest is $\beta$ that we expect to be positive and significant, thus confirming a positive correlation between productivity and each of our five quality of institutions variables.

In Table 4, models (1) to (10), we include the results obtained by the most parsimonious specification that introduces our five $E F F_{-} I N S T_{i}$ (one at a time) as the only regressor and, secondly, an alternative specification where we also add our two additional controls, human capital and dummy South. Overall, our parsimonious specifications results (models with odd numbers) show that all our quality of institutions variables have positive and significant coefficients. In particular, when we use our synthetic measure of institutional quality (identified in our Tables as overall index) in model (1) we obtain the highest R2. 
We continue our regression analysis by introducing two additional controls in our estimated model, human capital (measured as average years of education) and the dummy South. Using this specification (in Table 4, models with even numbers), we firstly observe that the coefficients on our two additional controls are always significant and with the expected sign, positive for human capital and negative for the dummy South. However, results on our estimated betas change. In particular, among our efficiency measures only the coefficient on Energy remains positive and significant (model 6), while coefficients on Overall index, Environment and Health are still positive (respectively, models 2, 4 and 10) but become non significant.

Finally, when we introduce our measure of the efficiency with which Educational infrastructures are provided, estimates reveal a puzzling negative and significant coefficient. In particular, models from (11) to (13) reveal that the change in sign is observed once we introduce our human capital indicator. In these specifications we jointly introduce our four specific public sector efficiency measures. Without further additional controls (model 11) these variables are all positive and significant, while introducing our human capital stock indicator the Educational infrastructures coefficient becomes negative (model 12). The two variables are, as expected, highly positively correlated and, therefore, multicollinearity may be one of the causes of this result. But this puzzling finding could also be due to endogeneity that it is likely to plague all OLS results. In the following sections we therefore describe how we deal with this issue.

\section{Does history matter? Empirical strategy and IV estimates}

As said above, in this framework the main difficulty is to assume that the main impact on economic performance runs through institutional settings and not vice versa. Quoting Acemoglu et al. (2001) "At some level it is obvious that institutions matter....Nevertheless, we lack reliable estimates of the effect of institutions on economic performance. It is quite likely that rich economies choose or can afford better institutions." 20 Needless to say, endogeneity is also likely to arise since measured "efficiency of institution" proxies may capture the effect of other factors omitted from the regression analysis or from measurement error. Both of these econometric problems are likely to affect estimates in this setting. In this

${ }^{20}$ Acemoglu et al. (2001), p. 1369. 
study we use a two-stage least square approach to deal with likely endogeneity issues. In particular:

$$
\begin{aligned}
& \text { First stage: } E F F_{-} I N S T_{i}=\delta+\theta H I S T_{i}+X_{i}^{\prime} \gamma+v_{i} \\
& \text { Second stage: } Y_{i}=\alpha+\beta E F F_{-} I N S T_{i}+X_{i}^{\prime} \gamma+\varepsilon_{i}
\end{aligned}
$$

where, HIST refers to some historical events/variable that may plausibly be assumed to have influenced current institutional quality and that affects current productivity only through that. Indeed, in macro empirical analysis history matters since it enables researchers to find good instruments and to get through on of the main difficulty they have to face in these cases. ${ }^{21}$ Having said that, how to specifically construct the instruments' set is not a straightforward choice since we need to identify historical facts/factors that have plausibly affected formal and/or informal past institutions level which, in turn, influence current institutional quality and, only through that, productivity. That is, we need to identify plausible critical historical facts that do not directly affect today's output but have led to divergent political-economic development paths across Italian regions through their persistent influence on current efficiency of governing institutions.

In our search for good instruments we rely on the different dominations that Italy has suffered during its long history since the end of the Roman Empire. Indeed, Italian history and its wide variability among dominators enable the creation of plausible instruments. To specifically address this issue, in this paper we follow two different approaches. First, we take a picture of the Italian political situation in which different areas were ruled by different Governments for a significantly long time. This would enable us to create a series of dummies, each representing a different domination, whose influence is assumed to have persisted over time. Our second approach extends the historical approach as far as it can and considers a wider period of time, seven hundred years, and it is based on the construction of a matrix of years of dominations. That is, for each province, we identify the number of years during which it has been governed by the various considered domination.

Overall, it is fair to say that we cannot assume that different dominations were fully random: they were in fact the result of a series of

${ }^{21}$ On this see also Angrist and Piescke (2010). 
historical processes. However, we claim that our instruments choice is plausible and robust to most possible problems. First of all, we focus on historical facts that took place in the distant past, when the Italian peninsula was seen - at least for its most part - by foreign realms as a conquered land. Therefore, most processes have been determined mainly by external factors and we can state that these processes were independent from the actual level of economic growth. An example is offered by the location of the Papal State. This was determined during the Roman Empire when the Pope chose to establish his base in Rome and, from then on, irrespective of the continuous political, social and economic turmoil and changes that took place over the centuries, has maintained his influence in this area of the country.

\subsection{First approach: dummy variables}

In this section we describe the first approach that, for each province, identifies the administration that ruled during a specific period of time. ${ }^{22}$ In this case, in order to avoid arbitrary choices, the specific historical period should be selected following certain criteria. These are described below:

- It has to be necessarily a period before the Italian Unity (1861). Since then, almost all current provinces had the same political structure and formal institutions.

- We need to focus on a period when the Italian peninsula was dominated/ruled by different formal governments.

- Each dominance must have lasted for a sufficiently long period. Although it is no guarantee, it is at least plausible that the longer the domination the greater its influence.

- Each province must have had the same formal government for the whole period.

A good candidate that meets all these criteria is certainly the historical period during which a large part of the Italian peninsula was dominated by the Spanish rule, namely, the period 1560-1659. Figure 5 (Part A) shows the Italian peninsula after the Cateau-Cambresis peace treaty (1559) that gave to Philip II of Spain the possession of the three kingdoms of Naples, Sicily and Sardinia, the duchy of Milan and the so-

${ }^{22}$ For details, see also Table A1, in Appendix. 
called "State of Presidi" 23 in Tuscany. The Spanish kingdom had a great influence in Italy for a long period of time, mainly during the 16th century and part of the 17th. Not many years after Columbus sailed for the Americas, in Italy the Spanish troops/kingdom had a direct control over 140,000 square kilometers (almost half) of the Italian peninsula and the Spanish influence was very strong in most of the Italian territory. Still, a significant part of the (northern) Italian peninsula maintained a certain degree of independence, in particular, the Republic of Venice (with all the Veneto and a great part of Lombardy), the Duchy of Savoy (with Piedmont, Nice and Savoy), the Grand-duchy of Tuscany, the Duchy of Parma and Piacenza, the Duchy of Mantua and Monferrato administrated by Gonzaga-Nevers, the Republic of Lucca and the Republic of Genoa.

Moreover, another reason that justifies our choice is that the Spanish hegemony has been often portrayed by historians as having negatively affected the dominated areas also through its legacy of inefficient bureaucracy. Since the focus of our paper is on the effect of the quality of governing institutions on development we test if this historic event has significantly influenced the quality of the current local public administration in Italy.

Some descriptive analysis offers additional hints. Figure 6 identifies with the (blue) dots all provinces in which the Spanish power have ruled for more than 150 years. Conversely, (red) triangles detect the provinces that were ruled for less than 150 years by the Spaniards or not conquered at all. Most provinces ruled by the Spanish for a long time are now characterized by low levels of productivity and low levels of institutional quality. Moreover, with the exception of some area located in the Northern part of the country (Lombardy and Piedmont) most ex-Spanish colonies were located in the south.

In sum, we expect past dominations to be correlated with the quality of governing institutions, which in turn influences VA per worker. In order to identify the different provincial administration/domination prevailing in each Italian province, in our first approach we construct a series of six dummies, that is, Spanish, Papal, Austrian, Venetian, Sabaudian and, finally, Independent areas.

\footnotetext{
23 This was a very small area of great strategic and military importance on the Maremma coast in Tuscany created by the will of King Philip II of Spain, and then entrusted with the Neapolitan territories.
} 
Figure 5 (Part B) allows to easily identify the geographical location of these dominations.

In our identification strategy we therefore depart from other similar studies on the Italian case that, following Putnam's (1993) contribution, usually identify the local political regimes in place across Italian regions in the middle ages as the fundamental determinant of current social capital. ${ }^{24}$ In particular, Putnam identifies the collapse of the Holy Roman Empire and the two political regimes that followed in Italy, the Norman Kings in the southern areas and the independent towns in the North, as the critical historical juncture that have influenced the degree of local civic commitment. In this view, independent towns were characterized by high levels of civicness, unlike southern regions ruled by the Norman autocratic regime, and civic capital is considered not only highly persistent over time, but also a key factor to explain current differences in Italian regional economic performance.

In Table 5 we show our IV estimator results: for each model, the first column reports the first stage estimates, namely the effect of dominations on current quality of institutions and the second one reports the second stage estimates. To check the goodness of our IV specifications, we include the p-value of the Sargan test of overidentifying restrictions to check the validity of our instruments and finally test whether our excluded instruments are independent of the error process. ${ }^{25}$

However, the feature that makes our instruments plausibly exogenous, that is, the fact that they occurred in the distant past, may also make our instruments weak. ${ }^{26}$ The instrument relevance issue in IV estimates has recently received increased attention by applied researchers, since weak instruments problems imply that the sampling distributions of IV statistics are non-normal and standard IV point estimates, hypothesis tests, and confidence intervals are unreliable. As a rule of thumb, we firstly check if the first-stage F-statistic is larger than

24 Among the most recent studies see Guiso et al. (2008), de Blasio and Nuzzo (2010) and Giordano and Tommasino (2011).

${ }^{25}$ Under the null hypothesis that all instruments are uncorrelated with the error process. We obtain almost identical results using the Basmann test.

26 "Finding exogenous instruments is hard work, and the features that make an instrument plausibly exogenous - for example, occurring sufficiently far in the past to satisfy a first order condition or the as-if random coincidence that lies behind a quasi-experiment - can also work to make the instrument weak". Stock et al. (2002), p.2. 
ten. ${ }^{27}$ Since we only have one endogenous variable we also conduct inference that is robust to weak instruments using Moreira's (2003) conditional likelihood ratio (CLR) test statistics. ${ }^{28}$ The latter enables us to create confidence intervals robust to weak instruments that we include among results, together with Limited Information Maximum Likelihood (LIML) estimates since they are more robust to weak instruments than standard IV. ${ }^{29}$

Models 1 and 2 in Table 5 refer to our broad indicator of the efficiency of institutions. As said above, we consider this as our main indicator of the local public administration efficiency. Model 1 shows the results of the parsimonious specification. In the first stage we observe that only the dummies referred to the Spanish domination and the Papal state are significant, and both show a negative sign, thus implying a negative correlation between these past administration and current institutional quality. Most of the remaining historical dummies show the expected sign, but they are not always significant. Conversely, in the second stage, results suggest that the influence of the quality of governing institutions on per worker VA is significant. In particular, the model 1 the coefficient on (overall) institutional quality implies that the difference between the efficiency of the governing institutions in Palermo (the province showing the lowest indicator) and that of Milan (the highest) explains up to $34 \%$ of the gap in productivity levels.

As expected, after inserting additional controls this percentage drops to $20 \%$, thus assuming a more realistic value that also confirm previous results found in empirical micro analysis. ${ }^{30}$ In particular, model 2 adds human capital, based on average years of education, and the usual

\footnotetext{
${ }^{27}$ In particular, Staiger and Stock (1997) and Stock and Yogo (2005) develop a test for weak instruments that, in its simplest form, rejects the null hypothesis of weak instruments if the first-stage $\mathrm{F}$ is bigger than ten.

${ }^{28}$ Moreira (2009) shows Monte Carlo simulations results where the CLR test for the endogenous variable's coefficient has good power overall in over-identified models and dominates the Anderson-Rubin and score tests. On this, see also Murray (2006).

${ }^{29}$ Reasons are twofold. First of all, the CLR test is centered around the LIML estimator. Secondly, LIML estimates are more robust to weak instruments than standard IV.

30 See for example, Carlin et al. (2010). Using micro data from a survey of managers' perceptions of the impact of institutions they estimate an aggregate impact on output of increasing public inputs in low-income countries to the high-income level of about $20 \%$.
} 
dummy South indicating if a province is located in the Mezzogiono. Note that, unlike OLS results, adding these additional controls, while reducing the value of the coefficient of our main parameters of interest, does not reduce its significance. Moreover, as in the OLS case, the human capital indicator is always positive and strongly significant. Its estimated coefficient implies an 18\% increase in productivity levels if the province with the lowest human capital endowments (Caltanisetta and Agrigento, both located in Sicily) would invest more in human capital accumulation than other areas and catch up with the best performer, that is, Rome. Finally, this time the dummy South is not significant. Thus, it seems that including our two main controls, quality of institutions and human capital, leaves no significant role for further geography or cultural unobserved factors. Interestingly, Acemoglu et al. (2001) find a similar result when they control for geography in their cross-country dataset. Unlike OLS, once they include their institutional proxy, neither distance from the equator nor the dummy for Africa were significant in TSLS suggesting that "...Africa is poorer than the rest of the world not because of pure geographic or cultural factors, but because of worse institutions". ${ }^{31}$

First stage results show a change in the sign of the Spanish government dummy: introducing the additional controls the coefficient becomes positive. However, note that, with the only exception of the Duchy of Milan, both the Spanish and South dummies identify the same provinces and this may explain the rather puzzling results we find with them in model 2. Furthermore, the positive sign on Spain could be also explained by some less conventional historical point of view on the Spanish domination. ${ }^{32}$ Finally, both in models 1 and 2 the overidentification restriction is not rejected in both models, even if the pvalue in model 2 is somewhat inconclusive, while the first stage Fstatistics is larger than ten, suggesting estimates are free from weak

\footnotetext{
31 See Acemoglu et al. (2001), p. 1372. Similar results can be also found in Rodrik et al. (2004).

32 See, for example Croce (1922). Unlike most historians, he maintained that the Spanish misgovernment was more a myth than a real historical fact. Moreover, Croce (1922) supported the idea that Italy would have been able to become independent from Spain as the Netherlands did, but it was too politically divided and weak. It is also said that, despite being administrated by the domination of Madrid, unlike the feudal domination applied in the Mezzogiorno, provinces in the Northern area of the Italian peninsula ruled by Spain enjoyed a relative autonomy. On this see also Sella and Capra (1984).
} 
instruments problems. This is confirmed by the confidence regions constructed using the CLR test that in model 1 shows similar lower and upper bounds than the Wald intervals reported, while in model 2 suggest that the effect of the quality of institutions may be even larger. ${ }^{33}$

Models from 3 to 10 introduce our specific quality of institutions indicators: Environment (models 3 and 4), Energy (models 5 and 6), Educational infrastructure (models 7 and 8) and Health (models 9 and 10). In general, the efficiency with which public provisions in these areas are provided is positively and significantly correlated with productivity. As in OLS estimates, the Educational infrastructure indicator seems to represent the only exception and we also observe that the interval constructed using the CLR test become unbounded suggesting lack of identification. Overall, these second stage results our previous results. However, the over-identifying test is sometimes rejected in these regressions, suggesting that an excessively specific definition of institutions may not fully capture the channels through which history affects current economic development. ${ }^{34}$

\subsection{Second approach: years matrix}

The dummy approach adopted so far may be subject to various criticisms. First of all, this method considers just a picture of the Italian history that, even with reasonable criteria of choice, limits our analysis to a short and specific period. Secondly, a system based on dummies is implicitly assuming that each different regime had the same importance and impact. Conversely, in principle it is likely that longer domination and regimes could have had a greater impact and left more persistent and lasting effects. Finally, in the dummy approach the Mezzogiorno is considered entirely as part of the Spanish domination and this implies that there is almost no variability in that area: as said above, this may explain the observed puzzling results on both the dummy South and that identifying the Spanish domination.

Therefore, unlike previous studies that usually focused on specific historical events, in this paper we follow a different path and

\footnotetext{
33 Unfortunately, while providing foundation for building confidence intervals, conditional likelihood test does not provide point estimates. For more on this see Murray (2006).

34 A similar interpretation can be found in Tabellini (2010). Unlike us, this paper focus on the effect of culture on development but find the same results on IV estimates when it introduces proxies based on narrow definitions of culture.
} 
collect data for all different regimes that governed each Italian province over seven centuries before the creation of the unified Italian State. Our historical analysis goes as far as it can in order to capture the main characteristics of past Italian dominations. In particular, we consider the period between 1100 and 1800 where the historical lower bound is determined by the high political instability of the Peninsula since the Holy Roman Empire downfall until the Norman rise (about 1100) and also by the absence of reliable historical documents. The upper bound has been chosen because since 1800 the Napoleonic era had established a situation of dramatic changes and instability in the Italian politics with a series of wars that finally triggered the Italian Unity. In sum, this approach enables us to overcome different criticisms that characterize the dummy approach. First of all, it inserts some variability in southern areas. Another advantage is that it takes into account all possible different influences that a specific territory has had during a long period of time, seven hundred years, thus introducing a more detailed analysis. Finally, it considers and weights the different levels of persistence that each domination has exerted on territories.

During these 700 years we have identified the following dominations: the Normans, the Swabians, the Anjou, the Spanish (Aragonese until 1502), the Bourbons, the Papal State, the Savoy, the Austrians and the Republic of Venice. ${ }^{35}$ Secondly, we have constructed a matrix that assigns to each province the number of years during which each regime has persisted in a specific territory. More historical details can be found in Appendix 3. Note that, as expected, in specific cases we had to rely on some simplifying assumptions. Problems arise mainly for small states, whose regimes were, in some cases, highly influenced by foreign powers and could thus be considered as ruled by them. Nevertheless, if not formally dominated, we identify these difficult cases as part of the independent states class.

Table 6 offers some descriptive statistics of our new set of instruments. The mean values column suggests a strong persistence of the Papal state and the Spanish domination in their territories. Moreover, we observe that some provinces have not experienced any change in regimes during the whole 700 years: this is true for provinces ruled by the Republic of Venice, the Savoy, the Papal state and it is also the case for some independent territory.

${ }^{35}$ I percorsi della Storia - Atlante, De Agostini, 1997. 
Table 7 shows the regression results of the second IV approach. That is, we replicate the previous analysis changing our set of instruments based on history. To avoid perfect multicollinearity we exclude, as before, the variable Independent states from the regression analysis and we have introduced, as before, two control variables in some of the specifications: a dummy for the South and one referred to human capital.

First stage results are very similar to the previous one found with the dummy approach and we confirm the conclusions of the previous section. The same is true for the second stage regressions results. With the usual exception of educational infrastructure, most institutional quality coefficients are positive and significant thus confirming, once again, the positive correlation existing between the efficiency of governing institutions and productivity. Results on our main indicator, that is, the synthetic index in models 1 and 2 , are almost identical to Table 5 in the parsimonious specification case (model 1), but when we include the dummy South and human capital (model 2) we find a smaller estimated coefficient of 0.013 that would imply that the difference between the efficiency of the governing institutions in Palermo (the province showing the lowest indicator) and that of Milan (the highest) explains approximately $7 \%$ gap in productivity levels. Finally, as previously found, confidence regions constructed using the CLR test show in most models lower and upper bounds that suggest that the effect of the quality of institutions could be even larger. ${ }^{36}$ That is, the instrumental variable estimates discussed so far portray a consistent picture on the role of (the broad index of) institutional efficiency on regional development. Results are very similar to those obtained suing the first dummy approach. However, in models 3 to 10 the overidentifying restriction tests always reject the null thus casting doubts on our second historical matrix IV approach.

\section{Robustness checks}

This section examines whether our previous results on the overall positive role of institutional quality for development are robust to a number of changes in the model specification. In particular, we will

\footnotetext{
${ }^{36}$ Main exceptions are in model 1 , where confidence regions constructed using the CLR test are very similar to the Wald ones, and model 10 where, again, we observe that the interval constructed using the CLR test become unbounded suggesting lack of identification.
} 
check if they are robust to the inclusion of further additional controls, and the use of different measures of regional economic performance.

We start from the first concern, that is, that regional differences in institutions efficiency are acting as a proxy for some omitted variable. As said in section 2 one of the most important controls in this context is social capital or, more precisely, alternative specific aspects of it that may be correlated with our measure of government efficiency.

In general, our analysis is related to the vast literature on social capital and development, where the specific analysis of the Italian regions' case dates back to Banfield (1958) and Putnam (1993) who also firstly raised the hypothesis that the observed within-country heterogeneity in informal institutions could be traced back to their distant histories. In these studies differences in economic performance across Italian regions are explained by different social capital endowments, with the latter showing a high persistency over time. ${ }^{37}$

To address this question, we therefore include to our basic IV specifications a composite measure of social capital provided by Cartocci (2007), described in Section 2, which should capture the role of specific "generalized morality", pro-social behavior and "interest in politics". 38 In principle it might be that, once the role of widely used measures of social capital is taken into account, no role is left for the efficiency of institutions as an independent determinant of economic development. Table 8 shows OLS and second stage TSLS (both dummies and matrix approaches) results obtained introducing this standard social capital measure as an additional regressor. Models from (1) to (3) introduce our new social capital variable together with our main index of institutional efficiency. In general, the social capital coefficient when significant shows an unexpected negative sign, while results on our quality of institutions indicator are almost invariably positive and significant. Similar results have been found in models (4) to (15) when the institutional quality variable is measured by the specific Environment, Energy, Schooling infrastructure and Health indices.

Our investigation therefore suggests that the effect of social capital on output might operate mainly or exclusively through the

\footnotetext{
${ }^{37}$ More recent papers are Guiso et al. (2008), Tabellini (2010), de Blasio and Nuzzo (2010), Mauro and Pigliaru (2011) and Giordano and Tommasino (2011).

${ }^{38} \mathrm{We}$ also perform the analysis assuming social capital is endogenous and find almost identical results. The same variable has been used in Mauro and Pigliaru (2011) and Giordano and Tommasino (2011).
} 
functioning and effectiveness of government institutions and that other specific factors, such as managerial practices or specific factors affecting the efficient provision of public services may be also playing an important role. ${ }^{39}$ Similar evidence on a regional Italian sample has been found in Tabellini (2010). In this case results show that introducing a measure of the quality of government institutions (measured by the average number of years needed to complete a first-degree civil lawsuit in courts) the effect of culture, a variable that closely resembles what in other studies is called "social capital", is significantly weakened: as in our case the coefficient of the latter becomes negative and insignificant. ${ }^{40}$

Secondly, we investigate our second point, that is, the sensitivity of results to a change in the dependent variable. During this part of the analysis we focus on results on our main quality of institutions indicator, that is, the synthetic index calculated as the sum of our four specific index since, as said above, it should capture the overall effect of administrative quality and it has also previously shown the best results in terms of significance and R-square. In Table 9 we therefore include the estimates obtained by using per worker Value Added in the three specific sectors, of agriculture, industry and services. This is because, first of all, it is likely that institutional efficiency affects some sector more than other. Secondly, public sector efficiency may indeed affect productivity through both a direct and an indirect channel, the first relating to changes of productivity within the public sector, the second by triggering off productivity in private production. The use of sectoral measures of regional economic performance as dependent variables enables us to address, even if imperfectly, this issue as well.

\footnotetext{
39 On this see Knack (2002) and Tabellini (2008) that both find culture to be strongly correlated with the functioning of government institutions across U.S. States (the former) and in a cross-country sample (the latter). More recently, Mauro and Pigliaru (2011) find that in Southern Italian regions the negative economic impact of otherwise constant low endowments of social capital has significantly increased as a consequence of a process of administrative decentralization occurred during the 70 s. In their model, devolution processes, making the local level of government responsible for the provision public goods, imply the latter is more likely to be influenced by local social capital levels.

${ }^{40}$ In Tabellini (2010) culture is measured by the first principal components extracted from four cultural variables (control, obedience, respect, trust). In this case, social capital is mainly captured by trust (having trust in other people) and respect.
} 
Section A of Table 9 introduces the results (only the second stage) obtained by using the first dummy approach, while section B shows the results obtained using the second matrix approach. Note that even in this case we do not include first stage results since they are identical to that shown in Tables 5 and 7. Table 9 shows results on our main regressor, our synthetic index of efficiency, almost invariably positive and significant. On the other hand, Table 8 suggests that public provision efficiency is more important for the industrial than for other sectors of the economy, agriculture and services. In particular, the overidentification restriction is never rejected for the former, even when we use the matrix approach, while the null is always rejected when we focus on the less innovative sectors. Overall, even if not conclusive, this evidence suggests that the effectiveness of government institutions acts mainly through an indirect effect on other sectors of the economy and, in particular, on its most innovative sector.

\section{Concluding remarks}

This paper investigates if institutional quality, measured by the public sector performance, has a positive impact on regional Italian productivity. The empirical literature of this topic faces two main problems: the first one relates to measurement problems of the quality of institution regressors, while the second relates to its likely endogeneity.

Our contribution dealing with these issues is twofold. First, we construct five public sector performance composite indicators for the 103 Italian provinces (or NUTS3 regions). To this aim we have collected data on seventeen different measures of the efficiency with which public services are provided by the local government in four key areas, namely, health, educational infrastructures, environment and energy. Next, we have calculated four specific institutional quality indices and identified a fifth synthetic indicator, our main institutional quality variable, computed as the sum of the former.

Second, in order to address endogeneity problems, we use the histories of the different foreign dominations that ruled Italian regions between the 16th and 17th century and over seven hundred years before the creation of the unified Italian State. In particular, we identify two new instruments sets. The first introduces a series of six dummies that identify which domination was present in each of the 103 Italian provinces during 1559-1660. A second approach does not select a specific or narrow historic episode, but takes into account all the different dominations that have ruled each Italian province over seven 
centuries (between 1100-1800) before the creation of the unified Italian State. In both cases, we assume that history does not directly affect today's output but entails different development paths across areas through its influence on current efficiency of governing institutions.

Overall, our two stage least squares estimates clearly suggest that policies directed at improving the public sector efficiency may represent an appropriate choice to significantly foster economic development. More specifically, overidentifying restrictions and weak instruments tests identify the first approach, the domination dummies approach, as the most appropriate. Our first stage results exhibit an invariably negative effect of the Papal administration, while the Spanish dummy shows the expected negative sign unless we also introduce a specific geographical dummy that nearly coincides with the former. Weaker results are observed for the remaining domination dummies that, nevertheless, almost invariably show the expected sign.

Second, TSLS results show that, when the public sector performance is measured by our synthetic indicator, its influence is most invariably positive and significant: the difference between the efficiency of the governing institutions in Palermo (the province showing the lowest value of efficiency) and that of Milan (the highest) explains up to $21 \%$ of the gap in productivity levels. Conversely, when we separately introduce detailed measures of public service provision (on health, educational infrastructure, environment and energy) we find less clearcut results, with the over-identifying tests sometimes rejected. This confirms the idea that the specific indicators are more likely to be influenced by local factors not necessarily related to the efficiency with which the public service is offered and they may not fully capture the channels through which history affects current economic development.

Third, our human capital coefficient is always positive and strongly significant in all specifications and implies large productivity gains in investments in education. Further, we find that including our two main controls, quality of institutions and human capital, leaves no significant role for the geographical dummy South. The latter is usually found in most studies to be negative and highly significant, while our results seems to suggest that the South of Italy is poorer than the rest of the country not because of pure geographic or other unobserved factors, but because of its worse public sector performance and lower human capital endowments.

In our robustness checks we control if our public administration efficiency measures do affect the different sector of the economy in 
similar or heterogeneous ways and find that public provision efficiency seems to affect the most innovative one, the industrial sector, more than agriculture or services. Finally, we also include among regressors a conventional measure of social capital. Social capital is probably the most important additional control in this setting since there is an extensive literature that investigates its role in Italian regional development and our efficiency of institutions variable could be capturing the effect of the former. This hypothesis is rejected by our results. Once institutional efficiency is controlled for, our social capital measure is almost always insignificant or even shows the wrong sign.

In sum, our analysis confirms that informal institutions matter for economic development, and that history can be used to find suitable instruments. They further suggest a more detailed analysis on the role played by the different components that affect the functioning of governing institutions and we aim to investigate this issue further in the next future.

\section{References}

Acemoglu D., Johnson S. and Robinson J. A. (2001), The Colonial Origins of Comparative Development: An Empirical Investigation, American Economic Review, Vol. 91 (5), 1369-1401

Acemoglu D., Johnson S. and Robinson J. A. (2002). Reversal of Fortune: Geography and Institutions in the Making of the Modern World, Quarterly Journal of Economics, 117, 1231-1294.

Afonso, A., Schuknecht, L. and Tanzi, V. (2005). "Public Sector Efficiency: An International Comparison," Public Choice, 123 (3-4), 321347.

Angrist J., S., Piescke (2010), The Credibility Revolution in Empirical Economics: How Better Research Design is Taking the Con out of Econometrics, Journal of Economic Perspectives, vol. 24(2), 3-30.

Banfield, E. G. (1958). The Moral Basis of a Backward Society. New York: Free Press. 
Becker S., K. Boeckh, C. Hainz, L. Woessmann (2011), The Empire Is Dead, Long Live the Empire! Long-Run Persistence of Trust and Corruption in the Bureaucracy, IZA Discussion Paper No. 5584

Becker S., L. Woessmann (2009), Was Weber Wrong? A Human Capital Theory of Protestant Economic History, The Quarterly Journal of Economics, vol. 124(2), 531-596.

Boix C., Posner D (1998), Social Capital: Its Origins and Effects on Governmental Performance, British Journal of Political Science, 28, 4. 686693

Bosker M., H. Garretsen (2009), Economic development and the geography of institutions, Journal of Economic Geography, 9, 295-328.

Botticini M. Z. Eckstein, (2011), The chosen few: how education shaped Jewish history, 70-1492, Princeton University Press, forthcoming.

Caravale M., Caracciolo A. (1978), Lo Stato pontificio da Martino V a Pio IX, UTET.

Carlin W., Schaffer M., Seabright P. (2010), A Framework for CrossCountry Comparisons of Public Infrastructure Constraints on Firm Growth, CEPR Discussion Papers no. 7662.

Cartocci R. (2007), Mappe del tesoro. Atlante del capitale sociale in Italia. Il Mulino, Bologna.

Cozzi G., Knapton M. (1986), La Repubblica di Venezia nell'età moderna, in Storia d'Italia, Vol. XII, UTET.

Croce B. (1922), La Spagna nella vita italiana durante la Rinascen₹a, Laterza.

De Blasio G., Nuzzo G. (2010), Historical traditions of civicness and local economic development, Journal of Regional Science, 20(10), 1-29.

Di Liberto A. (2008). Education and Italian Regional Development, Economics of Education Review, vol. 27, no.1, 94-107.

Dunan M., Piverteau J., Baumont M., Delorme J., Fossier R., Mazoyer L., Ruhlmann G. and Ristelhueben R. (1965), Storia Universale, Vol. I, Rizzoli. 
Eicher T., Leukert A. (2009), Institutions and Economic Performance: Endogeneity and Parameter Heterogeneity, Journal of Money, Credit and Banking, 41(1), 197-219.

Engerman S., Sokoloff K. (1997), Factor Endowments, Institutions, and Differential Paths of Growth Among New World Economies: A View from Economic Historians of the United States, in How Latin America Fell Behind (Haber S. ed.), Stanford University Press.

Engerman S., Sokoloff K. (2000), History Lessons Institutions, Factor Endowments, and Paths of Development in the New World, Journal of Economic Perspectives, vol. 14(3), 217-232.

Galasso G. (1994), Alla periferia dell'Impero, La Spagna imperiale e il Mezzogiorno, Einaudi.

Galasso G. (2005), Il Regno di Napoli, Il Mezzogiomo angioino e aragonese (1266-1494), vol. 15(1), UTET.

Giordano R., Tommasino P. (2011), Public sector efficiency and political culture, Working Papers Banca d'Italia n.786.

Glaeser and Shleifer (2002), Legal origins, Quarterly Journal of Economics, vol. 117(4), 1193-1229.

Guiso L., Sapienza P., Zingales L. (2008), Alfred Marshall Lecture Social Capital as Good Culture, Journal of the European Economic Association, vol. 6(2-3), 295-320.

Guiso L., Sapienza P., Zingales L. (2011), Civic Capital as the missing link, in Handbook of social economics (J. Benhabib, A. Bisin, M. Jackson eds.), Elsevier.

Hall R., Jones C. (1999), Why Do Some Countries Produce So Much More Output Per Worker Than Others?, Quarterly Journal of Economics, vol 114(1), 83-116.

Helmke G., Levitsky S. (2004), Informal Institutions and Comparative Politics: A Research Agenda, Perspectives on Politics, vol. 2(4), 725-740. 
Ichino A., Maggi G., (2000), Work Environment And Individual Background: Explaining Regional Shirking Differentials In A Large Italian Firm, The Quarterly Journal of Economics, vol. 115(3), 1057-1090.

ISTAT (2006), Atlante statistico dei comuni, Istituto Centrale di Statistica, Roma.

ISTAT (2008), Atlante statistico territoriale delle infrastrutture, Istituto Centrale di Statistica, Roma.

Knack S. (2002). Social Capital and the Quality of Government: Evidence from the States, American Journal of Political Science, 46, 772-785.

La Porta, R., Lopez-de-Silanes F., Shleifer A. (1999), The Quality of Government, Journal of Law, Economics, and Organization, 15, 222-279.

La Porta, R., Lopez-de-Silanes F., Shleifer A. (2008), The Economic Consequences of Legal Origins, Journal of Economic Literature, 46, 285332.

Mauro L., Pigliaru F. (2011). Capitale sociale, crescita e shock istituzionali: cosa ci insegna il caso del Mezzogiorno, in Il Capitale Sociale, Sestito P. and De Blasio G, eds., Donzelli, Roma.

Merlin P. (1994), Il Piemonte sabaudo: Stato e territori in età moderna, in Storia d'Italia, vol. VIII (G. Galasso ed.), ed. UTET, Torino.

Montanelli I., Gervaso M. (2003), Storia d'Italia, vol. 2 and 3, RCS.

Moreira M. (2009). "Tests with correct size when instruments can be arbitrarily weak," Journal of Econometrics, vol. 152(2), 131-140.

Murray M. (2006), Avoiding Invalid Instruments and Coping with Weak Instruments , Journal of Economic Perspectives, 20, 4, 111-132.

Nunn N. (2009), The Importance of History for Economic Development, Annual Review of Economics, vol 1, 65-92.

Pande R., Udry C. (2005), Institutions and Development: A View from Below, Economic Growth in Proceedings of the 9th World Congress of the Econometric Society (R. Blundell, W. Newey and T. Persson eds.) Cambridge University Press 2005, pp 349 - 403. 
Putnam, R. (1993), Making Democracy Work: Civic Tradition in Modern Italy. Princeton University Press.

Rodrik, D, Subramanian A., Trebbi F., (2004), Institutions rule, the primacy of institutions over geography and integration in economic development, Journal of Economic Growth, 9, 131-165.

Sella D., Capra C. (1984), Il Ducato di Milano dal 1535 al 1796, UTET.

Staiger, D., and Stock, J.H. (1997), Instrumental variables regression with weak instruments, Econometrica, 65(3), 557-586.

Stock, J.H., and Yogo, M. (2005), Testing for weak instruments in linear IV regression, in Identi cation and Inference for Econometric Models: Essays in Honor of Thomas Rothenberg, Cambridge University Press, 80-108.

Stock, J.H., Wright J., Yogo M. (2002), A Survey of Weak Instruments and Weak Identification in Generalized Method of Moments, Journal of Business \& Economic Statistics, vol. 20(4), 518-29.

Tabellini G. (2010), '"Culture and institutions: economic development in the regions of Europe, Journal of the European Economic Association, 8, 677716.

Tabellini, G. (2008), 'Presidential address: Institutions and Culture', Journal of the European Economic Association Papers and Proceedings, 6, 255-294.

Various Authors (1997), I percorsi della storia - Atlante, De Agostini. 
Figure 1 - Institutional quality: territorial distribution

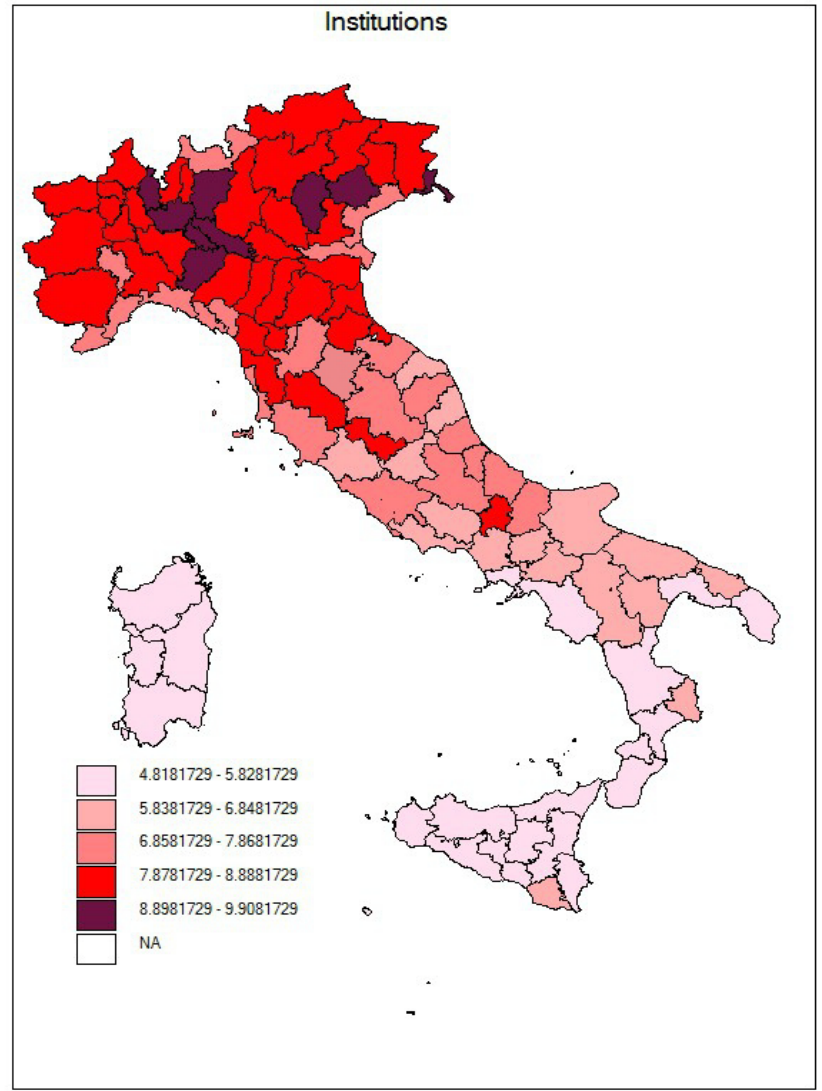

Notes: Figure 1 represents the territorial distribution across the 103 Italian provinces of our synthetic quality of institutions indicator calculated as the sum of four indicators on environment, energy, health and education. See ISTAT (2008). 
Figure 2 - Institutional quality: kernel density distribution

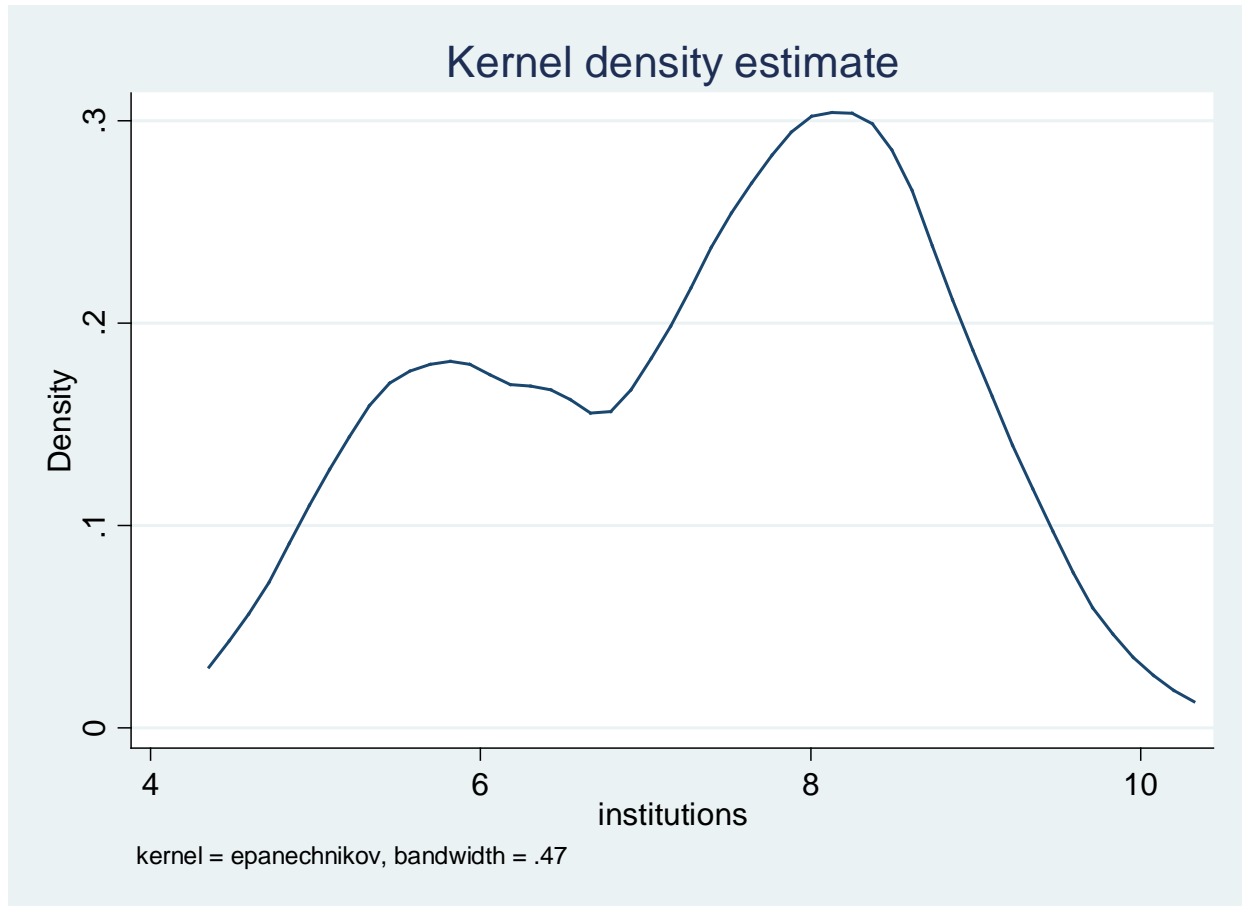

Notes: Figure 2 represents the Kernel distribution across the 103 Italian provinces of our synthetic quality of institutions indicator calculated as the sum of four indicators on environment, energy, health and education. See ISTAT (2008). 


\section{Figure 3 - Total value added: territorial distribution}

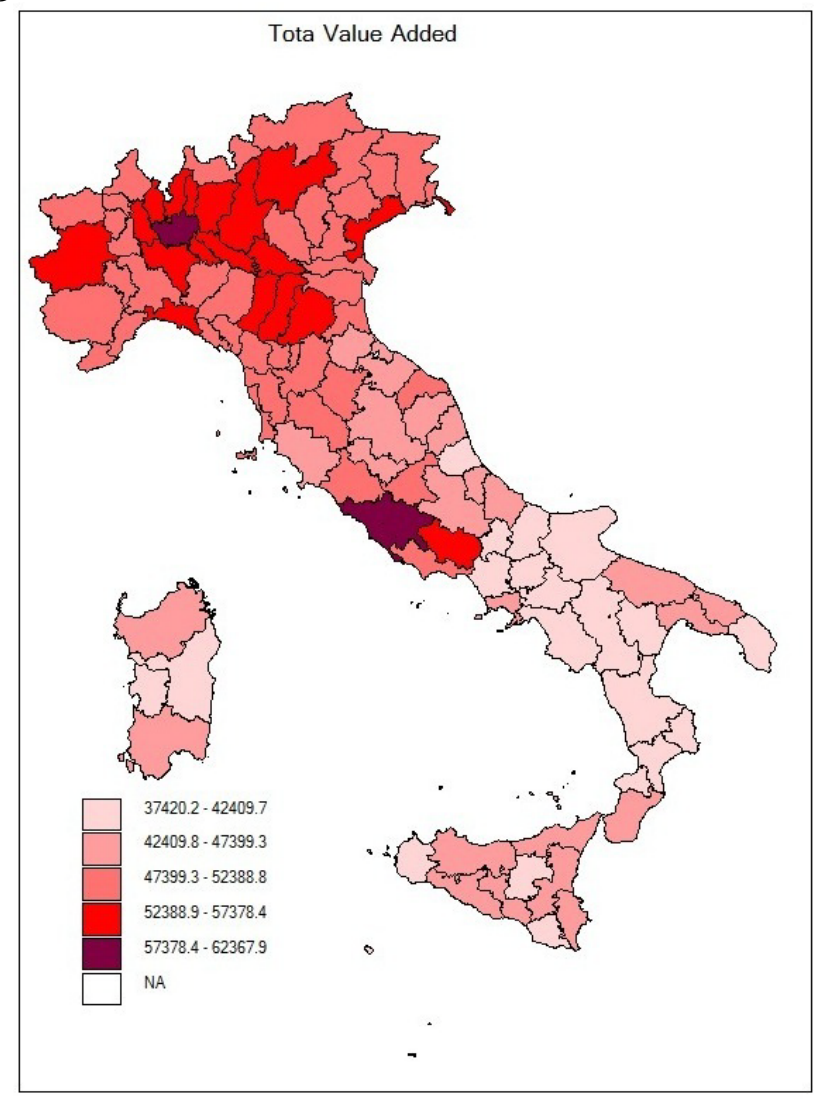

Notes: Figure 3 represents the Total VA territorial distributionacross the 103 Italian provinces, where the latter is the value added per worker (in euros) measured as average 2002-2005. See ISTAT (2006). 
Figure 4 - Productivity and quality of Institutions

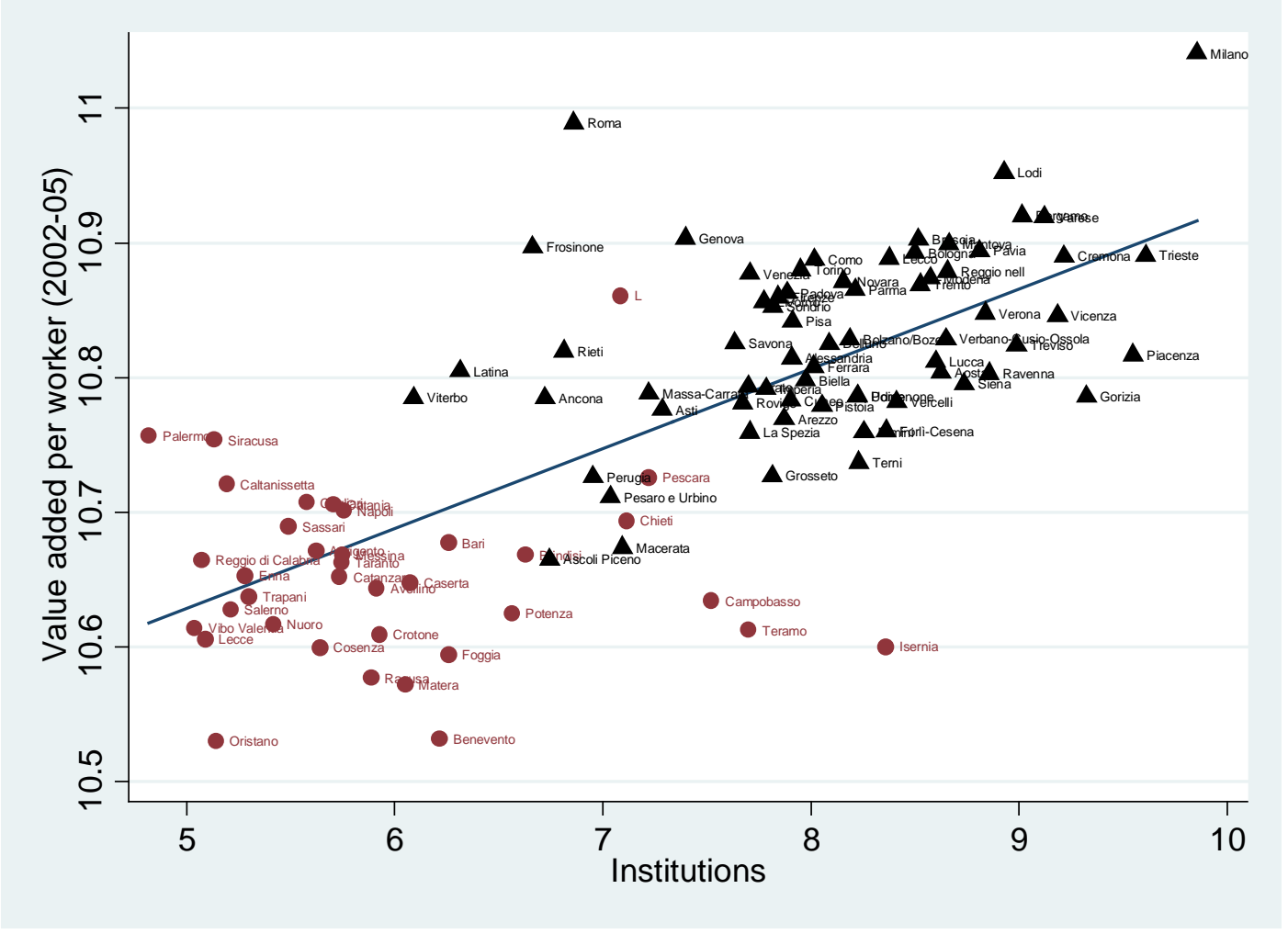

Notes: Value added per worker (in euros) measured as average 2002-2005 (vertical axis) and our synthetic quality of institutions indicator (horizontal axis) calculated as the sum of four indicators on environment, energy, health and education. Red dots identify Southern provinces, black triangles identify Centre and Northern provinces. Data sources are described in Appendix A1 
Figure 5: Italy during the period 1560-1659 (part A) and corresponding current provinces (part B)
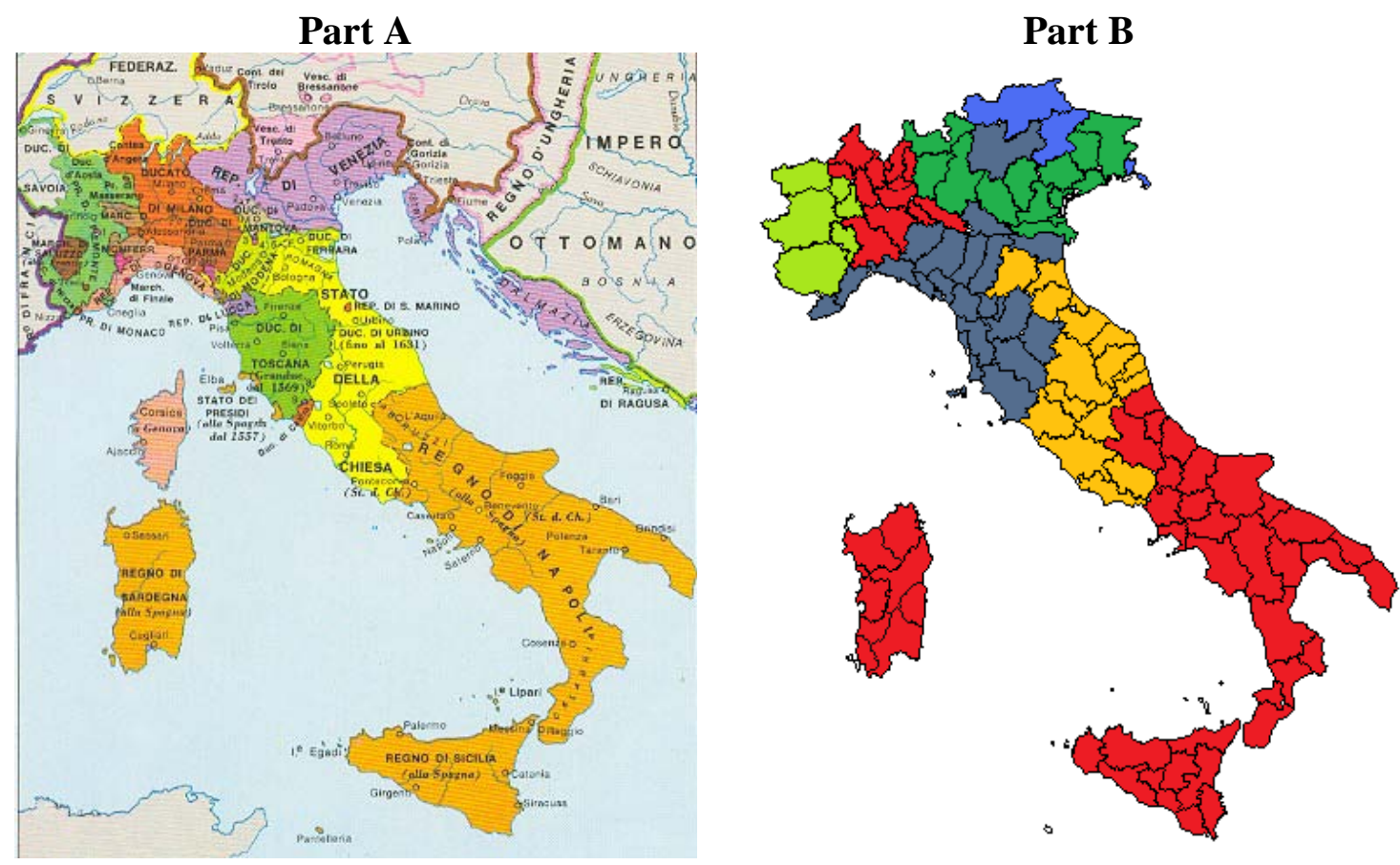

Notes: Part A: Italian dominations during the period 1560-1659. Historical map from Dunan et al. (1965). In part B we identify the corresponding current Italian provinces with Spanish, Papal, Austrian, Venetian, Sabaudian domination and other Indipendent provinces. 


\section{Figure 6 -Former Spanish provinces}

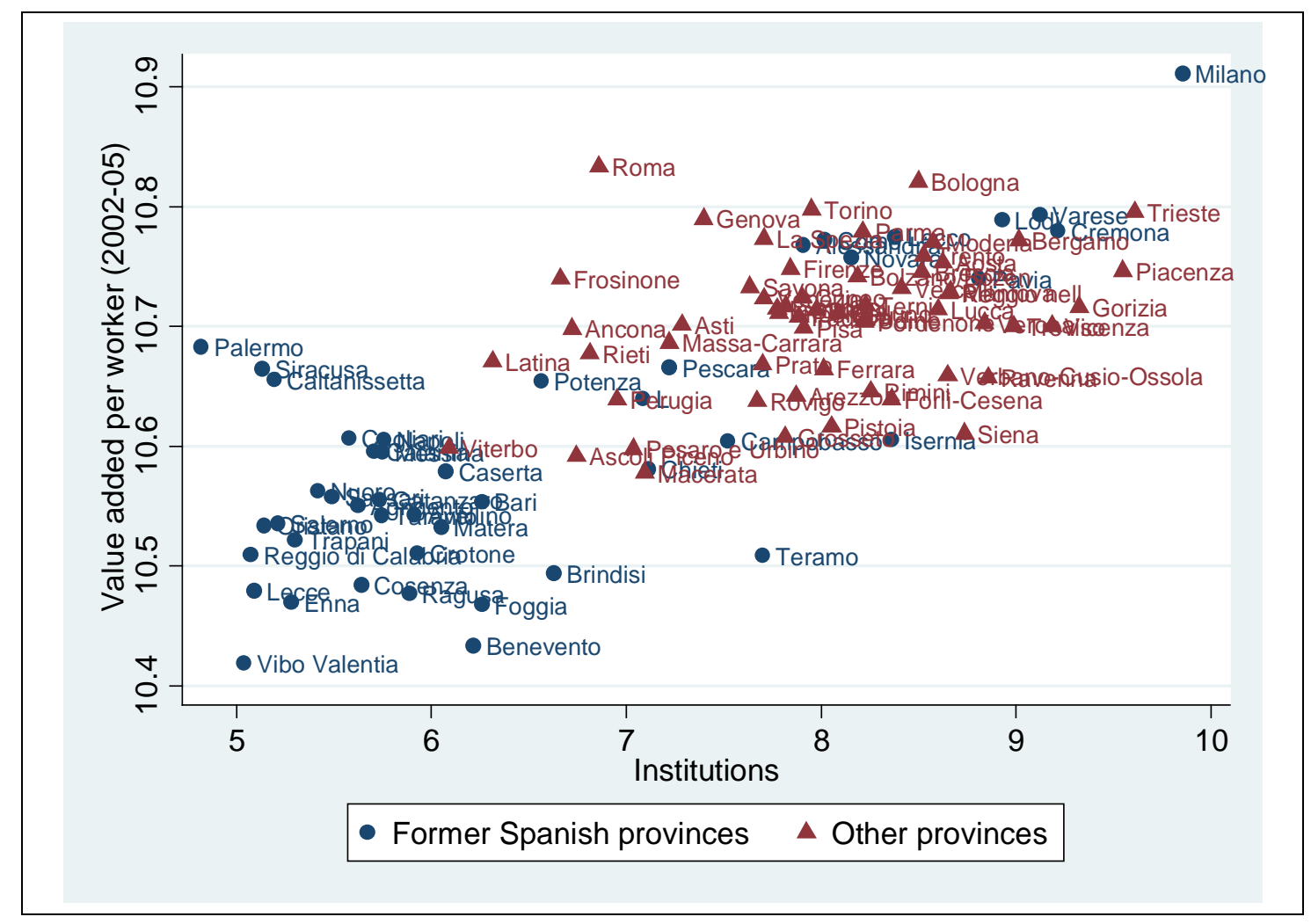

Notes: (blue) dots identify Italian provinces under the Spanish control, (red) triangles identify the remaining provinces during the period 1560-1659. 
Table 1 - Descriptive statistics: Institutional quality indicators

\begin{tabular}{|c|c|c|c|c|c|c|}
\hline $\begin{array}{l}\text { Part A: Efficiency of } \\
\text { institutions indicators }\end{array}$ & $\begin{array}{l}\text { No. of } \\
\text { components }\end{array}$ & Obs. & Mean & Std. Dev. & $\begin{array}{l}\text { Min. value (and } \\
\text { corresponding } \\
\text { province) }\end{array}$ & $\begin{array}{l}\text { Max. value (and } \\
\text { corresponding } \\
\text { province) }\end{array}$ \\
\hline & & & & & (Vibo Valentia, South) & (Trieste, North) \\
\hline $\begin{array}{l}\text { 1) Environment } \\
----------\end{array}$ & $\begin{array}{c}7 \\
------\end{array}$ & $\begin{array}{l}103 \\
---\end{array}$ & 2.206 & $\begin{array}{c}0.587 \\
-----\end{array}$ & $\begin{array}{c}1.023 \\
\text { (Sassari, South) }\end{array}$ & $\begin{array}{c}3.755 \\
------ \\
\text { (Milan, North) }\end{array}$ \\
\hline 2) Energy & 3 & 103 & 1.104 & 0.352 & 0.001 & 2.198 \\
\hline
\end{tabular}

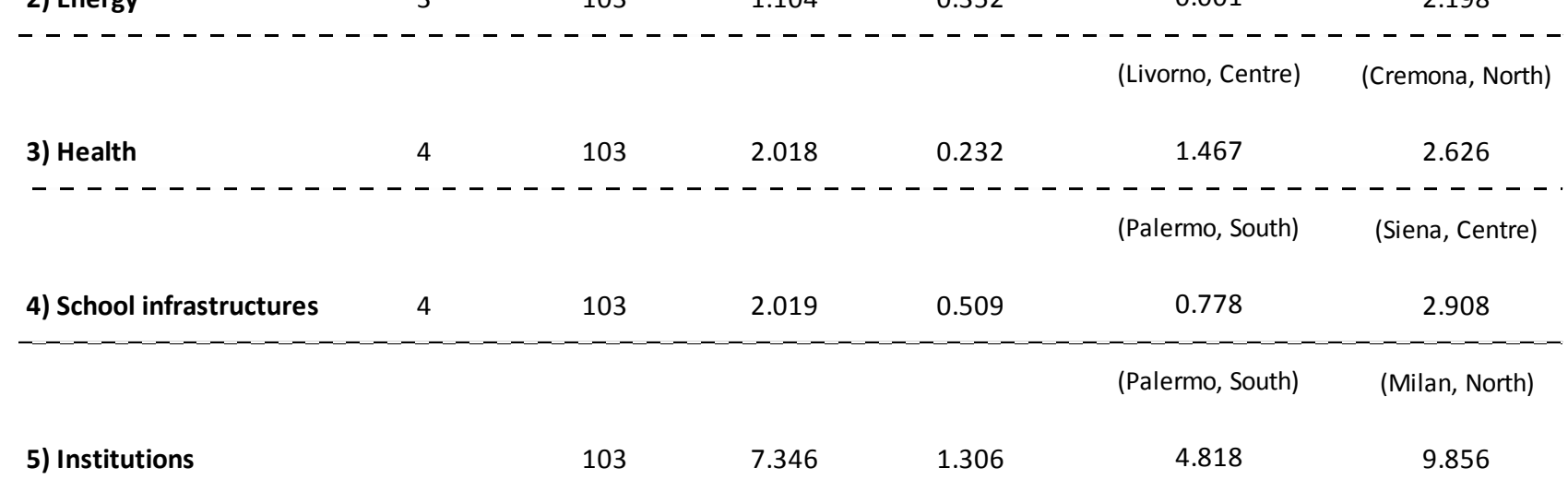

Part B: Correlation Matrix

\begin{tabular}{|c|c|c|c|c|c|}
\hline & Environment & Energy & Health & $\begin{array}{c}\text { School } \\
\text { infrastructures }\end{array}$ & Institutions \\
\hline Environment & 1 & & & & \\
\hline Energy & 0.46 & 1 & & & \\
\hline Health & 0.42 & 0.49 & 1 & & \\
\hline School infrastructures & 0.41 & 0.46 & 0.56 & 1 & \\
\hline Institutions & 0.81 & 0.74 & 0.72 & 0.8 & 1 \\
\hline
\end{tabular}

Notes: Panel A: Variables (1) to (4) are the sum of different standardized components (or specific provision of public services) described in Appendix A1. Column 2 specifies the number of public provision components included in each variable. For each component, standardisation is performed using the method of distance. Variable 5, Institutions, represents the sum of (1) to (4). The last two columns include for each indicator its minimum and maximum value and specify the corresponding province and macro-area (in brackets). Panel B includes the correlation matrix of these variables. Data sources are described in Appendix A1. 
Table 2 - Descriptive statistics: Dependent variables

\begin{tabular}{lccccc}
\hline Variables & Obs. & Mean & Std. Dev. & Min & Max \\
\hline Total value added per worker & 103 & 47726 & 5096094 & 37420 & 62368 \\
Sectoral VA per worker: & & & & & \\
Agriculture & 103 & 22270 & 5556272 & 10102 & 40243 \\
Industry & 103 & 46141 & 6026684 & 33363 & 60763 \\
Services & 103 & 51689 & 4319835 & 43568 & 63665 \\
\hline
\end{tabular}

Notes: Value Added measures (in euros) are average values of the 2002-2006 period. Data sources are described in Appendix A1. 
Table 3 - Descriptive statistics: Additional Controls

\begin{tabular}{|c|c|c|c|c|c|}
\hline Variables & Obs. & Mean & Std. Dev. & Min & Max \\
\hline Average years of education (2001) & 103 & 8.96 & 0.453 & 7.94 & 10.09 \\
\hline Upper Secondary education (2001) & 103 & $25.35 \%$ & 2.4 & $19.50 \%$ & $32.82 \%$ \\
\hline Tertiary education (2001) & 103 & $6.84 \%$ & 1.2 & $4.50 \%$ & $12.28 \%$ \\
\hline Illiterate - all (2001) & 103 & $1.53 \%$ & 1.3 & $0.25 \%$ & $5.39 \%$ \\
\hline Illiterate - over 45 (1971) & 103 & $12.42 \%$ & 10.5 & $0.33 \%$ & $42.26 \%$ \\
\hline Social Capital & 103 & -0.0003 & 3.13 & -6.43 & 5.47 \\
\hline
\end{tabular}

Notes: Average years of education (AVEDU) for each province is estimated as AVEDU $=\Sigma j$ YRj* $H K j$, where $\mathrm{j}$ is the schooling level, YRj is the number of years of schooling represented by level $j$, and $\mathrm{HKj}$ is the fraction of the labour force for which the jth level of education represents the highest level attained. Within the Italian system, primary school lasts eight years, the secondary level is usually attained after five years, and university courses take four to six years. Social capital merges data on 1) blood donations, 2) sport participation, 3) dissemination of newspaper and 4) voter turnout. The remaining variables are the percentage values of the labor force with specific educational attainments. Data sources and methodologies are described in Appendix A1. 


\section{Table 4: OLS estimates}

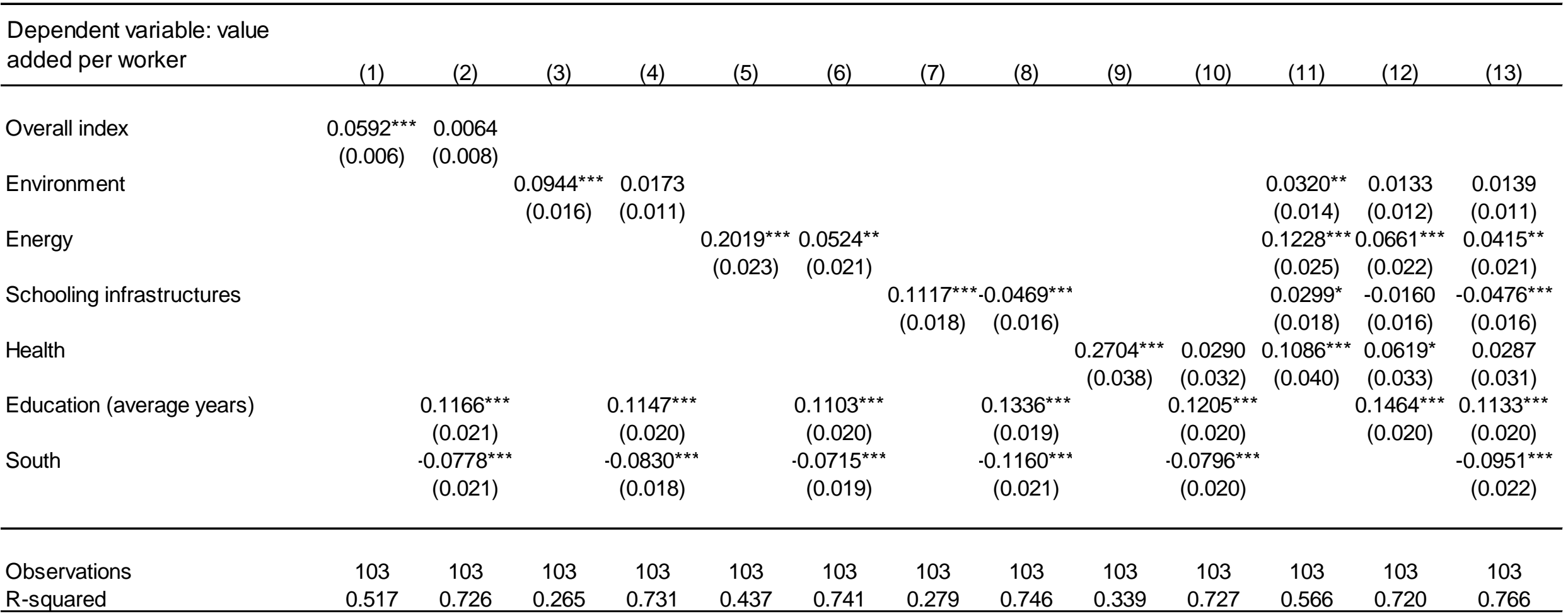

Notes: Standard errors in parentheses: ${ }^{* *} p<0.01,{ }^{* *} p<0.05, * p<0.1$. In columns (1)-(2) we show the OLS results when we introduce our synthetic quality of institutions indicator. In columns, (3) to (10) we include, alternatively, our four specific quality of institutions indicators: environment, energy, schooling infrastructures and health. Finally, models (11)-(13) introduce our four specific measures altogether. Additional controls are Education, measured as average years of education, and South that is a dummy variable equal to one for provinces located in the southern areas of the country. See Appendix A1 for more detailed variable definitions and sources. 
Table 5 - IV results: First approach

\begin{tabular}{|c|c|c|c|c|c|c|c|c|c|c|c|c|c|c|c|c|c|c|c|c|}
\hline \multirow{3}{*}{$\begin{array}{l}\text { Dependent variable: value } \\
\text { added per worker }\end{array}$} & \multicolumn{4}{|c|}{ Overall index } & \multicolumn{4}{|c|}{ Environment } & \multicolumn{4}{|c|}{ Energy } & \multicolumn{4}{|c|}{ Schooling infrastructures } & \multicolumn{4}{|c|}{ Health } \\
\hline & \multicolumn{2}{|c|}{ (1) } & \multicolumn{2}{|c|}{ (2) } & \multicolumn{2}{|c|}{ (3) } & \multicolumn{2}{|c|}{ (4) } & \multicolumn{2}{|c|}{ (5) } & \multicolumn{2}{|c|}{ (6) } & \multicolumn{2}{|c|}{ (7) } & \multicolumn{2}{|c|}{ (8) } & \multicolumn{2}{|c|}{ (9) } & \multicolumn{2}{|c|}{ (10) } \\
\hline & first stage & TSLS & first stage & TSLS $\quad f i$ & first stage & TSLS $f$ & first stage & TSLS fi & first stage & TSLS & first stage & TSLS $f$ & first stage & e TSLS fil & first stage & TSLS fi & first stage & TSLS fil & first stage & TSLS \\
\hline Austria & $\begin{array}{l}0.6971 \\
(0.561)\end{array}$ & & $\begin{array}{l}0.4555 \\
(0.373)\end{array}$ & & $\begin{array}{c}1.0174^{\star \star \star} \\
(0.266)\end{array}$ & & $\begin{array}{c}0.9396^{\star \star \star} \\
(0.229)\end{array}$ & & $\begin{array}{l}0.0829 \\
(0.174)\end{array}$ & & $\begin{array}{l}0.0199 \\
(0.144)\end{array}$ & & $\begin{array}{c}-0.3980^{*} \\
(0.212)\end{array}$ & & $\begin{array}{c}-0.4755^{\star *} \\
(0.183)\end{array}$ & & $\begin{array}{l}-0.0052 \\
(0.109)\end{array}$ & & $\begin{array}{l}-0.0285 \\
(0.089)\end{array}$ & \\
\hline Papal State & $\begin{array}{c}-0.9703^{\star \star \star} \\
(0.361)\end{array}$ & & $\begin{array}{c}-0.8912^{\star \star \star} \\
(0.237)\end{array}$ & & $\begin{array}{c}-0.5145^{\star \star \star} \\
(0.171)\end{array}$ & & $\begin{array}{c}-0.4890^{\star \star \star} \\
(0.146)\end{array}$ & & $\begin{array}{l}-0.0946 \\
(0.112)\end{array}$ & & $\begin{array}{l}-0.0740 \\
(0.092)\end{array}$ & & $\begin{array}{l}-0.1966 \\
(0.136)\end{array}$ & & $\begin{array}{c}-0.1712 \\
(0.116)\end{array}$ & & $\begin{array}{c}-0.1646^{\star \star} \\
(0.070)\end{array}$ & & $\begin{array}{l}0.1570^{\star \star \star} \\
(0.057)\end{array}$ & \\
\hline Savoy & $\begin{array}{l}0.0090 \\
(0.448)\end{array}$ & & $\begin{array}{l}0.1024 \\
(0.294)\end{array}$ & & $\begin{array}{l}-0.0136 \\
(0.212)\end{array}$ & & $\begin{array}{l}0.0165 \\
(0.181)\end{array}$ & & $\begin{array}{l}0.0534 \\
(0.139)\end{array}$ & & $\begin{array}{l}0.0778 \\
(0.114)\end{array}$ & & $\begin{array}{l}-0.1963 \\
(0.169)\end{array}$ & & $\begin{array}{l}-0.1663 \\
(0.144)\end{array}$ & & $\begin{array}{l}0.1654^{*} \\
(0.087)\end{array}$ & & $\begin{array}{l}0.1744^{\star *} \\
(0.070)\end{array}$ & \\
\hline Spain & $\begin{array}{c}-1.5969 \star * \star \star \\
(0.268)\end{array}$ & & $\begin{array}{l}0.4763^{*} \\
(0.269)\end{array}$ & & $\begin{array}{c}-0.2912^{\star \star} \\
(0.127)\end{array}$ & & $\begin{array}{c}0.4154^{\star *} \\
(0.166)\end{array}$ & & $\begin{array}{l}0.2880^{\star \star \star} \\
(0.083)\end{array}$ & & $\begin{array}{l}0.2048^{\star} \\
(0.104)\end{array}$ & & $\begin{array}{c}-0.7924^{\star \star \star} \\
(0.101)\end{array}$ & & $\begin{array}{c}-0.2579^{\star} \\
(0.132)\end{array}$ & & $\begin{array}{c}-0.2254^{\star \star \star} \\
(0.052)\end{array}$ & & $\begin{array}{l}0.1141^{*} \\
(0.064)\end{array}$ & \\
\hline Venice & $\begin{array}{l}0.2895 \\
(0.370)\end{array}$ & & $\begin{array}{l}0.3252 \\
(0.242)\end{array}$ & & $\begin{array}{l}0.3844^{\star *} \\
(0.176)\end{array}$ & & $\begin{array}{c}0.3959^{\star * \star} \\
(0.149)\end{array}$ & & $\begin{array}{l}0.1266 \\
(0.115)\end{array}$ & & $\begin{array}{l}0.1359 \\
(0.094)\end{array}$ & & $\begin{array}{l}-0.1978 \\
(0.140)\end{array}$ & & $\begin{array}{l}-0.1863 \\
(0.119)\end{array}$ & & $\begin{array}{l}-0.0237 \\
(0.072)\end{array}$ & & $\begin{array}{l}-0.0203 \\
(0.058)\end{array}$ & \\
\hline Education (average years) & & & $\begin{array}{c}0.8439^{\star \star \star} 0 \\
(0.241)\end{array}$ & $\begin{array}{c}0.0779 * \star \star \\
(0.028)\end{array}$ & & & $\begin{array}{l}0.2720^{*} \\
(0.149)\end{array}$ & $\begin{array}{c}0.1018^{\star \star \star} \\
(0.022)\end{array}$ & & & $\begin{array}{c}0.2201^{\star *} \\
(0.093)\end{array}$ & $\begin{array}{l}0.0483 \\
(0.041)\end{array}$ & & & $\begin{array}{c}0.2708^{\star *} C \\
(0.118)\end{array}$ & $\begin{array}{l}0.1368^{\star \star \star} \\
(0.022)\end{array}$ & & & $\begin{array}{l}0.0811 \\
(0.058)\end{array}$ & $\begin{array}{c}0.1073^{\star \star \star} \\
(0.022)\end{array}$ \\
\hline South & & & $\begin{array}{l}-2.0114^{\star \star \star} \\
(0.329)\end{array}$ & $\begin{array}{l}-0.0293 \\
(0.031)\end{array}$ & & & $\begin{array}{c}-0.6962^{* \star *} \\
(0.202)\end{array}$ & $\begin{array}{c}(0.019) \\
(0.0779 * \star\end{array}$ & & & $\begin{array}{c}-0.4646^{\star \star \star} \\
(0.127)\end{array}$ & $\begin{array}{r}-0.0012 \\
(0.043)\end{array}$ & & & $\begin{array}{l}0.4820^{* \star_{-}-(} \\
(0.161)\end{array}$ & $\begin{array}{l}0.1252^{\star \star \star} \\
(0.039)\end{array}$ & & & $\begin{array}{l}0.3685^{\star \star \star} \\
(0.079)\end{array}$ & $\begin{array}{l}-0.0495^{*} \\
(0.027)\end{array}$ \\
\hline Institutional quality (TSLS) & & $\begin{array}{l}0.0673^{\star \star \star} \\
(0.009)\end{array}$ & & $\begin{array}{c}0.0422^{\star \star} \\
(0.017)\end{array}$ & & $\begin{array}{l}0.1101^{\star \star \star} \\
(0.027)\end{array}$ & & $\begin{array}{c}0.0427^{\star \star} \\
(0.019)\end{array}$ & & $\begin{array}{c}0.3551^{\star \star \star} \\
(0.059)\end{array}$ & & $\begin{array}{c}0.2996^{\star \star} \\
(0.115)\end{array}$ & & $\begin{array}{c}0.1592^{\star \star \star} \\
(0.028)\end{array}$ & & $\begin{array}{l}-0.0614 \\
(0.055)\end{array}$ & & $\begin{array}{c}0.3948^{\star \star \star} \\
(0.074)\end{array}$ & & $\begin{array}{l}0.1564^{\star \star} \\
(0.076)\end{array}$ \\
\hline Institutional quality (LIML) & & 0.0684 & & 0.0577 & & 0.1418 & & 0.0552 & & 0.3611 & & 0.3289 & & 0.166 & & -1.8338 & & 0.4757 & & 0.2677 \\
\hline Wald (95\%) & & {$[0.049,0.085$} & & $0.009,0.076]$ & & $0.057,0.164$ & & {$[.004,0.081]$} & & {$[0.237,0.473]$} & & {$[0.071,0.528]$} & & {$[0.104,0.214]$} & & $.170,0.047]$ & & {$[0.248,0.541]$} & & {$[0.006,0.307]$} \\
\hline CLR (95\%) & & {$[0.050,0.089$} & & $0.022,0.122]$ & & $0.066,0.245$ & & {$[0.014,0.109]$} & & {$[0.255,0.549]$} & & {$[0.143,1.617]$} & & {$[0.111,0.232]$} & {$[-\infty,-0.1$} & $188] \cup[0.15$ & $57,+\infty) \quad[0$ & {$[0.310,0.739]$} & & {$[0.082,0.685]$} \\
\hline Observations & 103 & 103 & 103 & 103 & 103 & 103 & 103 & 103 & 103 & 103 & 103 & 103 & 103 & 103 & 103 & 103 & 103 & 103 & 103 & 103 \\
\hline R-squared & 0.406 & 0.507 & 0.752 & 0.664 & 0.340 & 0.258 & 0.535 & 0.717 & 0.213 & 0.185 & 0.489 & 0.377 & 0.444 & 0.228 & 0.607 & 0.744 & 0.286 & 0.268 & 0.550 & 0.684 \\
\hline $\begin{array}{l}\text { F-test } \\
\text { Sargan test }\end{array}$ & 13.27 & 0.298 & 41.08 & 0.0832 & 9.99 & $8.48 \mathrm{e}-05$ & 15.63 & 0.0144 & 5.25 & 0.933 & 12.98 & 0.921 & 15.47 & 0.215 & 20.94 & 0.00123 & 7.77 & 0.0149 & 16.56 & 0,0239 \\
\hline
\end{tabular}

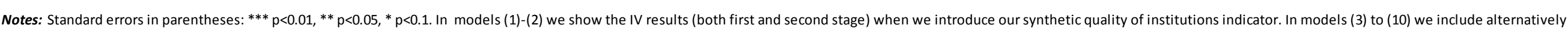

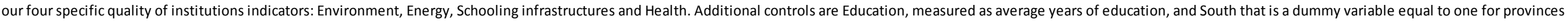

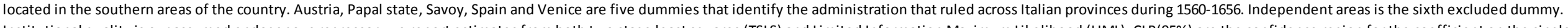

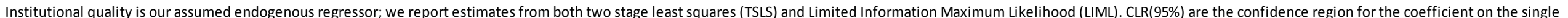

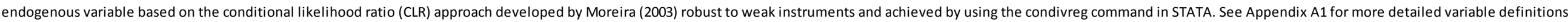
and sources. 
Table 6 - Years of dominations over 7 centuries (1100-1800)

\begin{tabular}{lccc} 
Dominator & $\begin{array}{c}\text { Average length of time } \\
\text { in power }\end{array}$ & Shortest period (years) & Longest period (years) \\
\hline Normans & 33 & 0 & 114 \\
Swabians & 22 & 0 & 166 \\
Anjou & 43 & 0 & 176 \\
Spanish & 125 & 0 & 411 \\
Bourbons & 20 & 0 & 66 \\
Papal & 100 & 0 & 700 \\
Indipendent & 247 & 0 & 700 \\
Venetian & 40 & 0 & 700 \\
Austrian & 34 & 0 & 437 \\
Savoy & 31 & 0 & 700 \\
\hline
\end{tabular}

Notes: The average length of time in power refers to the average number of years (across our 103 Italian provinces) during which these dominations ruled in the Italian peninsula during $1100-1800$. 
Table 7 - TSLS results: Second approach

\begin{tabular}{|c|c|c|c|c|c|c|c|c|c|c|c|c|c|c|c|c|c|c|c|c|}
\hline \multirow{3}{*}{$\begin{array}{l}\text { Dependent variable: } \\
\text { value added per worker }\end{array}$} & \multicolumn{4}{|c|}{ Overall index } & \multicolumn{4}{|c|}{ Environment } & \multicolumn{4}{|c|}{ Energy } & \multicolumn{4}{|c|}{$\underline{\text { Schooling infrastructures }}$} & \multicolumn{4}{|c|}{$\underline{\text { Health }}$} \\
\hline & \multicolumn{2}{|c|}{ (1) } & \multicolumn{2}{|c|}{ (2) } & \multicolumn{2}{|c|}{ (3) } & \multicolumn{2}{|c|}{ (4) } & \multicolumn{2}{|c|}{ (5) } & \multicolumn{2}{|c|}{ (6) } & \multicolumn{2}{|c|}{ (7) } & \multicolumn{2}{|c|}{ (8) } & \multicolumn{2}{|c|}{ (9) } & \multicolumn{2}{|r|}{ (10) } \\
\hline & first stage & TSLS & first stage & TSLS fir & first stage & TSLS fil & first stage & TSLS fir & first stage & TSLS & first stage & TSLS & first stage & TSLS & first stage & e TSLS fir & first stage & e TSLS & first stage & TSLS \\
\hline \multirow[t]{2}{*}{ Normans } & \multirow{2}{*}{\multicolumn{2}{|c|}{$\begin{array}{c}-0.0151 \\
-0.1\end{array}$}} & \multirow{2}{*}{$\begin{array}{c}0.0055 \\
(0.0092)\end{array}$} & & \multirow{2}{*}{$\begin{array}{l}-0.0044 \\
(0.006)\end{array}$} & & \multirow{2}{*}{$\begin{array}{r}-0.0002 \\
(0.006)\end{array}$} & & \multirow{2}{*}{$\begin{array}{l}0.0037 \\
(0.004)\end{array}$} & & \multirow{2}{*}{$\begin{array}{c}0.0139 * \star * \\
(0.003)\end{array}$} & & \multirow{2}{*}{$\begin{array}{c}-0.0086^{\star \star} \\
(0.004)\end{array}$} & & \multirow{2}{*}{$\begin{array}{l}-0.006 \\
(0.004)\end{array}$} & & $-0.0059^{\star \star}$ & & -0.0025 & \\
\hline & & & & & & & & & & & & & & & & & $(0.002)$ & & $(0.002)$ & \\
\hline Swabians & $0.0051^{\star}$ & & -0.0014 & & -0.00001 & & -0.0015 & & $0.0031^{\star \star \star}$ & & -0.0001 & & 0.0004 & & -0.0004 & & $0.0016^{\star *}$ & & 0.0005 & \\
\hline & -0.003 & & $(0.003)$ & & $(0.002)$ & & $(0.002)$ & & $(0.001)$ & & $(0.001)$ & & $(0.001)$ & & $(0.001)$ & & $(0.001)$ & & $(0.001)$ & \\
\hline Angiò & 0.0032 & & $0.0054^{\star \star}$ & & 0.0018 & & 0.0022 & & -0.0017 & & -0.0006 & & $0.0024^{\star}$ & & 0.0027 & & 0.0007 & & $0.0011^{*}$ & \\
\hline & $(0.0031)$ & & $(0.0026)$ & & $(0.002)$ & & $(0.002)$ & & $(0.001)$ & & $(0.001)$ & & $(0.001)$ & & $(0.001)$ & & $(0.001)$ & & $(0.001)$ & \\
\hline Spain & $-0.0051^{\star \star \star}$ & & 0.0021 & & -0.000001 & & 0.0016 & & $-0.0022^{\star \star \star}$ & & $0.0012^{\star \star}$ & & $-0.0021^{\star \star \star}$ & & -0.0012 & & $-0.0008^{\star \star \star}$ & & 0.0004 & \\
\hline & $(0.001)$ & & $(0.0015)$ & & $(0.001)$ & & $(0.001)$ & & $(0.000)$ & & $(0.000)$ & & $(0.000)$ & & $(0.001)$ & & $(0.000)$ & & $(0.000)$ & \\
\hline Borbonic & 0.0028 & & -0.0077 & & -0.0057 & & -0.0077 & & -0.001 & & -0.007 & & 0.0042 & & 0.0034 & & $0.0053^{*}$ & & 0.0035 & \\
\hline & $(0.0123)$ & & $(0.0107)$ & & $(0.007)$ & & $(0.007)$ & & $(0.004)$ & & $(0.003)$ & & $(0.005)$ & & $(0.005)$ & & $(0.003)$ & & $(0.003)$ & \\
\hline Papal state & $-0.0021^{\star \star \star}$ & & $-0.0018^{\star \star \star}$ & & $-0.001^{\star \star *}$ & & $-0.0009^{\star \star \star}$ & & -0.0003 & & -0.0001 & & $-0.0006^{\star \star \star *}$ & & $-0.0005^{* *}$ & & $-0.0003^{\star \star \star}$ & & $-0.0003^{\star \star \star}$ & \\
\hline & $(0.0005)$ & & $(0.0004)$ & & $(0.0003)$ & & $(0.000)$ & & $(0.000)$ & & $(0.000)$ & & $(0.000)$ & & $(0.000)$ & & $(0.000)$ & & $(0.000)$ & \\
\hline Venice & $\begin{array}{l}0.0001 \\
(0.001)\end{array}$ & & $\begin{array}{l}0.0006 \\
(0.001)\end{array}$ & & $\begin{array}{l}0.001^{\star \star} \\
(0.000)\end{array}$ & & $\begin{array}{c}0.0009^{* *} \\
(0.000)\end{array}$ & & $\begin{array}{l}0.0001 \\
(0.000)\end{array}$ & & $\begin{array}{l}0.0003 \\
(0.000)\end{array}$ & & $\begin{array}{c}-0.0006^{* *} \\
(0.000)\end{array}$ & & $\begin{array}{c}-0.0006^{*} \\
(0.000)\end{array}$ & & $\begin{array}{c}-0.0002 \\
(0.000)\end{array}$ & & $\begin{array}{l}-0.0001 \\
(0.000)\end{array}$ & \\
\hline Austria & $\begin{array}{c}0.0029^{\star \star} \\
(0.001)\end{array}$ & & $\begin{array}{l}0.0017^{\star} \\
(0.001)\end{array}$ & & $\begin{array}{c}0.003^{\star \star \star} \\
(0.001)\end{array}$ & & $\begin{array}{c}0.0026^{\star \star \star *} \\
(0.001)\end{array}$ & & $\begin{array}{l}0.0006 \\
(0.000)\end{array}$ & & $\begin{array}{l}0.0001 \\
(0.000)\end{array}$ & & $\begin{array}{l}-0.0007 \\
(0.000)\end{array}$ & & $\begin{array}{c}-0.0009^{\star} \\
(0.000)\end{array}$ & & $\begin{array}{l}0.0001 \\
(0.000)\end{array}$ & & $\begin{array}{l}-0.0001 \\
(0.000)\end{array}$ & \\
\hline Savoy & $\begin{array}{l}-0.0006 \\
(0.001)\end{array}$ & & $\begin{array}{r}-0.0002 \\
(0.001)\end{array}$ & & $\begin{array}{r}-0.0002 \\
(0.000)\end{array}$ & & $\begin{array}{r}-0.0001 \\
(0.000)\end{array}$ & & $\begin{array}{l}-0.0002 \\
(0.000)\end{array}$ & & $\begin{array}{l}0.0000 \\
(0.000)\end{array}$ & & $\begin{array}{c}-0.0005^{*} \\
(0.000)\end{array}$ & & $\begin{array}{r}-0.0004 \\
(0.000)\end{array}$ & & $\begin{array}{l}0.0003^{*} \\
(0.000)\end{array}$ & & $\begin{array}{c}0.0004^{\star *} \\
(0.000)\end{array}$ & \\
\hline Education (average years) & & & $\begin{array}{l}0.6912^{\star \star \star} \\
(0.235)\end{array}$ & $\begin{array}{l}0.1091^{\star * \star} \\
(0.024)\end{array}$ & & & $\begin{array}{l}0.226 \\
(0.153)\end{array}$ & $\begin{array}{c}0.1091^{\star * *} \\
(0.022)\end{array}$ & & & $\begin{array}{c}0.1907^{\star \star \star} \\
(0.072)\end{array}$ & $\begin{array}{c}0.1067^{\star \star \star} \\
(0.020)\end{array}$ & & & $\begin{array}{c}0.189 \\
(0.116)\end{array}$ & $\begin{array}{c}0.1487^{\star \star \star} \\
(0.039)\end{array}$ & & & $\begin{array}{l}0.0856 \\
(0.059)\end{array}$ & $\begin{array}{c}0.1189^{\star * *} \\
(0.021)\end{array}$ \\
\hline South & & & $\begin{array}{l}-3.0378^{\star \star \star} \\
(0.6495)\end{array}$ & $\begin{array}{c}-0.0684^{\star *} \\
(0.025)\end{array}$ & & & $\begin{array}{l}-0.647 \\
(0.422)\end{array}$ & $\begin{array}{c}-0.0808^{\star \star *} \\
(0.019)\end{array}$ & & & $\begin{array}{c}-1.5355^{\star \star \star} \\
(0.199)\end{array}$ & $\begin{array}{c}{ }^{*}-0.0674^{\star \star \star} \\
(0.0199)\end{array}$ & & & $\begin{array}{l}-0.348 \\
(0.320)\end{array}$ & $\begin{array}{l}-0.160^{\star \star \star} \\
(0.031)\end{array}$ & & & $\begin{array}{l}-0.5069^{\star \star \star} \\
(0.162)\end{array}$ & $\begin{array}{c}-0.0759^{\star \star \star} \\
(0.024)\end{array}$ \\
\hline Institutional quality (TSLS) & & $\begin{array}{c}0.068^{\star \star \star} \\
(0.007)\end{array}$ & & $\begin{array}{l}0.0133 \\
(0.013)\end{array}$ & & $\begin{array}{l}0.1418^{\star \star \star} \\
(0.023)\end{array}$ & & $\begin{array}{l}0.0282 \\
(0.018)\end{array}$ & & $\begin{array}{l}0.2703^{\star \star \star} \\
(0.036)\end{array}$ & & $\begin{array}{c}0.0668^{* *} \\
(0.030)\end{array}$ & & $\begin{array}{c}0.1673^{\star \star \star} \\
(0.023)\end{array}$ & & $\begin{array}{c}-0.1163^{\star \star \star} \\
(0.039)\end{array}$ & & $\begin{array}{c}0.4055^{\star \star \star} \\
(0.057)\end{array}$ & & $\begin{array}{l}0.0442 \\
(0.064)\end{array}$ \\
\hline Institutional quality (LIML) & & 0.0719 & & 0.0288 & & 0.2017 & & 0.0736 & & 0.41 & & 0.078 & & 0.1937 & & -0.2087 & & 0.522 & & 0.3426 \\
\hline Wald (95\%) & & $0.054,0.082]$ & & $-0.012,0.039]$ & & {$[0.097,0.187]$} & & {$[-0.008,0.065]$} & & $0.200,0.341]$ & & {$[0.008,0.126]$} & & $0.121,0.214]$ & & $-0.193,-0.040]$ & & {$[0.293,0.518]$} & & {$[-0.083,0.171]$} \\
\hline CLR (95\%) & & $0.058,0.087]$ & & $-0.011,0.084]$ & & {$[0.150,0.275]$} & & {$[-0.005,0.109]$} & & $0.313,0.576]$ & & {$[0.012,0.149]$} & & $0.148,0.250]$ & & $-0.591,-0.094]$ & & {$[0.399,0.698]$} & & $(-\infty,+\infty)$ \\
\hline Observations & 103 & 103 & 103 & 103 & 103 & 103 & 103 & 103 & 103 & 103 & 103 & 103 & 103 & 103 & 103 & 103 & 103 & 103 & 103 & 103 \\
\hline R-squared & 0.68 & 0.506 & 0.786 & 0.724 & 0.519 & 0.198 & 0.553 & 0.728 & 0.449 & 0.387 & 0.725 & 0.74 & 0.637 & 0.21 & 0.659 & 0.67 & 0.497 & 0.255 & 0.576 & 0.726 \\
\hline $\begin{array}{l}\text { F-test } \\
\text { Sargan test }\end{array}$ & 21.94 & 0.0055 & 30.39 & 0.0014 & 11.14 & 0.0001 & 10.22 & 0.002 & 8.41 & 0.000 & 21.79 & 0.0037 & 18.15 & 0.0049 & 15.97 & 0.0619 & 10.2 & 0.0011 & 11.23 & 0.001 \\
\hline
\end{tabular}

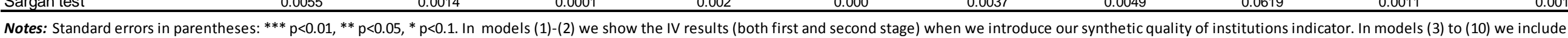

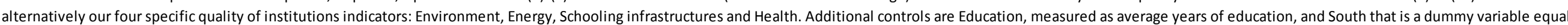

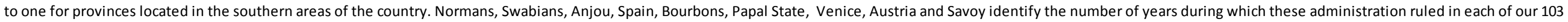

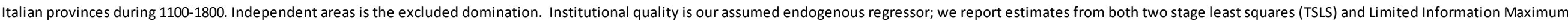

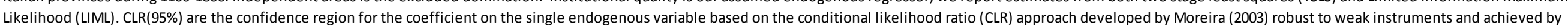
using the condivreg command in STATA. See Appendix A1 for more detailed variable definitions and sources. 
Table 8 - Additional controls: Social Capital (second stage results)

\begin{tabular}{|c|c|c|c|c|c|c|c|c|c|c|c|c|c|c|c|}
\hline \multirow[b]{2}{*}{$\begin{array}{l}\text { Dependent variable: value } \\
\text { added per worker }\end{array}$} & \multicolumn{3}{|c|}{$\underline{\text { Overall index }}$} & \multicolumn{3}{|c|}{ Environment } & \multicolumn{3}{|c|}{ Energy } & \multicolumn{3}{|c|}{ Schooling infrastructures } & \multicolumn{3}{|c|}{ Health } \\
\hline & $\begin{array}{l}\text { OLS } \\
(1)\end{array}$ & $\begin{array}{l}\text { IV-dummies } \\
\text { (2) }\end{array}$ & $\begin{array}{c}\text { IV-matrix } \\
\text { (3) }\end{array}$ & $\begin{array}{l}\text { OLS } \\
(4)\end{array}$ & $\begin{array}{l}\text { IV-dummies } \\
\text { (5) }\end{array}$ & $\begin{array}{c}\text { IV-matrix } \\
(6)\end{array}$ & $\begin{array}{l}\text { OLS } \\
(7)\end{array}$ & $\begin{array}{l}\text { IV-dummies } \\
\text { (8) }\end{array}$ & $\begin{array}{c}\text { IV-matrix } \\
\text { (9) }\end{array}$ & $\begin{array}{l}\text { OLS } \\
(10)\end{array}$ & $\begin{array}{l}\text { IV-dummies } \\
\text { (11) }\end{array}$ & $\begin{array}{c}\text { IV-matrix } \\
(12)\end{array}$ & $\begin{array}{l}\text { OLS } \\
(13)\end{array}$ & $\begin{array}{l}\text { IV-dummies } \\
\text { (14) }\end{array}$ & $\begin{array}{l}\text { IV-matrix } \\
\text { (15) }\end{array}$ \\
\hline Education (average years) & $\begin{array}{l}0.1232 * * * \\
(0.022)\end{array}$ & $\begin{array}{c}0.0904^{\star * \star} \\
(0.027)\end{array}$ & $\begin{array}{l}0.1141^{* * *} \\
(0.023)\end{array}$ & $\begin{array}{l}0.1234^{* * *} \\
(0.021)\end{array}$ & $\begin{array}{c}0.1148^{\star \star *} \\
(0.022)\end{array}$ & $\begin{array}{c}0.1169^{* * *} \\
(0.022)\end{array}$ & $\begin{array}{c}0.1139 * * * \\
(0.022)\end{array}$ & $\begin{array}{l}0.0379 \\
(0.048)\end{array}$ & $\begin{array}{l}0.1092^{* \star *} \\
(0.023)\end{array}$ & $\begin{array}{c}0.1336^{\star * *} \\
(0.020)\end{array}$ & $\begin{array}{c}0.1322 * * * \\
(0.021)\end{array}$ & $\begin{array}{c}0.1369^{* * *} \\
(0.021)\end{array}$ & $\begin{array}{l}0.1282^{* * *} \\
(0.021)\end{array}$ & $\begin{array}{c}0.1182^{* * *} \\
(0.023)\end{array}$ & $\begin{array}{c}0.1260 * * * \\
(0.021)\end{array}$ \\
\hline South & $\begin{array}{c}-0.0887^{\star \star \star} \\
(0.023)\end{array}$ & $\begin{array}{c}-0.0508^{\star} \\
(0.029)\end{array}$ & $\begin{array}{c}-0.0781^{\star \star \star} \\
(0.025)\end{array}$ & $\begin{array}{c}-0.0992^{\star * \star} \\
(0.021)\end{array}$ & $\begin{array}{c}-0.1013^{\star \star \star} \\
(0.022)\end{array}$ & $\begin{array}{c}-0.1008^{\star \star \star} \\
(0.022)\end{array}$ & $\begin{array}{c}-0.0767^{\star \star *} \\
(0.023)\end{array}$ & $\begin{array}{l}0.0168 \\
(0.056)\end{array}$ & $\begin{array}{c}-0.0709 * \star \star \\
(0.025)\end{array}$ & $\begin{array}{c}-0.1160^{\star \star \star} \\
(0.022)\end{array}$ & $\begin{array}{c}-0.1072^{\star \star *} \\
(0.034)\end{array}$ & $\begin{array}{c}-0.1373^{\star * *} \\
(0.027)\end{array}$ & $\begin{array}{c}-0.0910^{\star \star \star} \\
(0.022)\end{array}$ & $\begin{array}{c}-0.0650^{\star *} \\
(0.027)\end{array}$ & $\begin{array}{c}-0.0851^{\star * *} \\
(0.025)\end{array}$ \\
\hline Social Capital & $\begin{array}{l}-0.0043 \\
(0.003)\end{array}$ & $\begin{array}{l}-0.0094^{\star *} \\
(0.004)\end{array}$ & $\begin{array}{l}-0.0057 \\
(0.004)\end{array}$ & $\begin{array}{l}-0.0050 \\
(0.003)\end{array}$ & $\begin{array}{c}-0.0071^{\star *} \\
(0.004)\end{array}$ & $\begin{array}{c}-0.0066^{\star} \\
(0.004)\end{array}$ & $\begin{array}{l}-0.0013 \\
(0.003)\end{array}$ & $\begin{array}{l}0.0071 \\
(0.006)\end{array}$ & $\begin{array}{l}-0.0008 \\
(0.003)\end{array}$ & $\begin{array}{l}0.0000 \\
(0.003)\end{array}$ & $\begin{array}{l}-0.0015 \\
(0.006)\end{array}$ & $\begin{array}{l}0.0037 \\
(0.004)\end{array}$ & $\begin{array}{l}-0.0036 \\
(0.003)\end{array}$ & $\begin{array}{l}-0.0053 \\
(0.004)\end{array}$ & $\begin{array}{l}-0.0040 \\
(0.003)\end{array}$ \\
\hline Institutional quality (TSLS) & $\begin{array}{l}0.0094 \\
(0.008)\end{array}$ & $\begin{array}{c}0.0506^{\star \star *} \\
(0.018)\end{array}$ & $\begin{array}{l}0.0209 \\
(0.013)\end{array}$ & $\begin{array}{l}0.0225^{\star} \\
(0.012)\end{array}$ & $\begin{array}{c}0.0489 * \star \\
(0.019)\end{array}$ & $\begin{array}{c}0.0426^{\star \star} \\
(0.019)\end{array}$ & $\begin{array}{c}0.0502^{* *} \\
(0.022)\end{array}$ & $\begin{array}{c}0.2759^{\star *} \\
(0.112)\end{array}$ & $\begin{array}{c}0.0640^{* *} \\
(0.032)\end{array}$ & $\begin{array}{c}-0.0469^{\star \star \star} \\
(0.018)\end{array}$ & $\begin{array}{l}-0.0245 \\
(0.069)\end{array}$ & $\begin{array}{c}-0.1007^{\star *} \\
(0.042)\end{array}$ & $\begin{array}{l}0.0337 \\
(0.033)\end{array}$ & $\begin{array}{c}0.1686^{\star *} \\
(0.076)\end{array}$ & $\begin{array}{l}0.0641 \\
(0.064)\end{array}$ \\
\hline Institutional quality (LIML) & & 0.0598 & 0.0354 & & 0.0579 & 0.0654 & & 0.3493 & 0.0762 & & 2.3042 & -0.2615 & & 0.2597 & 0.2685 \\
\hline $\begin{array}{l}\text { Wald (95\%) } \\
\text { CLR (95\%) }\end{array}$ & & $\begin{array}{l}{[0.016,0.086][-(} \\
{[0.025,0.118][}\end{array}$ & $\begin{array}{l}{[-0.005,0.046]} \\
{[0.003,0.079]}\end{array}$ & & $\begin{array}{l}{[0.011,0.087][} \\
{[0.018,0.108][}\end{array}$ & $\begin{array}{l}{[0.004,0.081]} \\
{[0.016,0.133]}\end{array}$ & & $\begin{array}{l}{[0.053,0.499][C} \\
{[0.140,3.019][0}\end{array}$ & $\begin{array}{l}{[0.001,0.127]} \\
{[0.002,0.157]}\end{array}$ & $(-\infty,-0$ & $\begin{array}{l}{[-0.162,0.113]-C} \\
-0.300] \cup[0.14-2\end{array}$ & $\begin{array}{l}-0.183,-0.018] \\
-2.619,-0.096]\end{array}$ & & $\begin{array}{l}{[0.017,0.320]} \\
{[0.082,0.628]}\end{array}$ & $\begin{array}{c}{[-0.063,0.191]} \\
{[-0.067,43.769]}\end{array}$ \\
\hline Observations & 103 & 103 & 103 & 103 & 103 & 103 & 103 & 103 & 103 & 103 & 103 & 103 & 103 & 103 & 103 \\
\hline R-squared & 0.731 & 0.656 & 0.725 & 0.737 & 0.724 & 0.729 & 0.741 & 0.458 & 0.740 & 0.746 & 0.742 & 0.722 & 0.730 & 0.683 & 0.728 \\
\hline $\begin{array}{l}\text { F-test (First stage) } \\
\text { Sargan test }\end{array}$ & & $\begin{array}{l}40.75 \\
0.283\end{array}$ & $\begin{array}{c}33.13 \\
0.0037\end{array}$ & & $\begin{array}{c}17.04 \\
0.0359\end{array}$ & $\begin{array}{l}10.47 \\
0.0075\end{array}$ & & $\begin{array}{l}12.83 \\
0.674\end{array}$ & $\begin{array}{c}19.76 \\
0.0037\end{array}$ & & $\begin{array}{c}21.84 \\
0.00119\end{array}$ & $\begin{array}{c}17.41 \\
0.0145\end{array}$ & & $\begin{array}{c}14.90 \\
0.0451\end{array}$ & $\begin{array}{c}10.60 \\
0.0017\end{array}$ \\
\hline
\end{tabular}

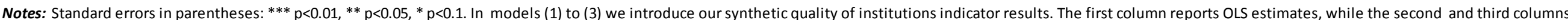

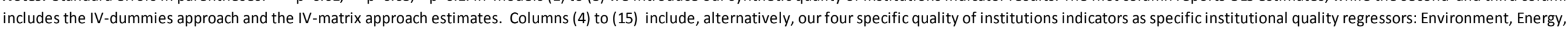

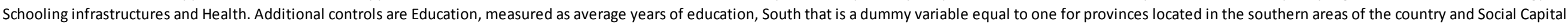

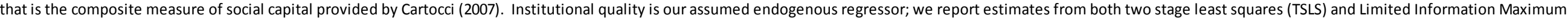

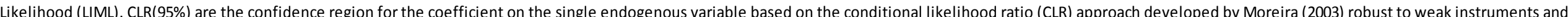
achieved by using the condivreg command in STATA. See Appendix A1 for more detailed variable definitions and sources. 
Table 9- Sector-specific analysis: IV (second stage) results

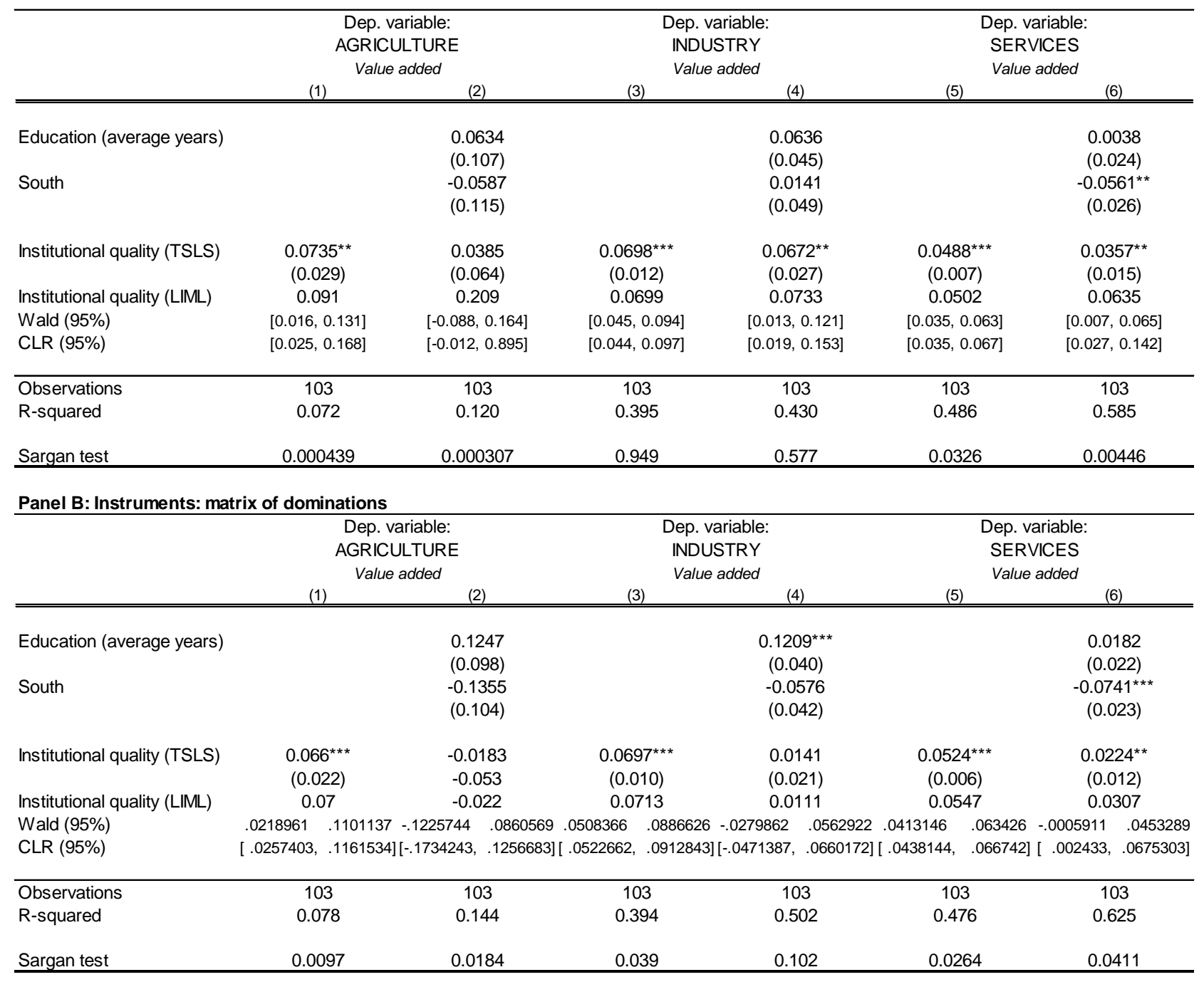

Notes: Standard errors in parentheses: *** $p<0.01,{ }^{* *} p<0.05,{ }^{*} p<0.1$. Panel A shows the results obtained using the first approach (dummies), while Panel $B$ shows the results of the second approach (matrix of dominations). We only include second stage results (first stage results are in Tables 5 and 7). Models (1) and (2) use the Value added per worker in Agriculture as dependent variable, while (3)-(4) and (5)-(6) refers, respectively, to per worker VA in Industry and Senvices. Institutional quality is measured by the overall index and it is our assumed endogenous regressor; we report estimates from both two stage least squares (TSLS) and Limited Information Maximum Likelihood (LIML). CLR (95\%) is the confidence region for the coefficient on the single endogenous variable based on the conditional likelihood ratio (CLR) approach developed by Moreira (2003), robust to weak instruments and achieved by using the condiveg command in STATA. See Appendix A1 for more detailed variable definitions and sources. 


\section{APPENDIX}

\section{A1. Data sources}

\section{Dependent Variables}

- Total value added per worker: average 2002-2005, in euros. From Istat (2006).

- Value added per worker in the agricultural sector:average 2002-2005, in euros. From Istat (2006).

- Value added per worker, in the industrial sector:average 2002-2005, in euros. From Istat (2006).

- Value added per worker in the service sector:average 2002-2005, in euros. From Istat (2006).

\section{Public administration efficiency variables}

Our specific institutional efficiency variables are composed by:

\section{1) Environment:}

- functioning purification plant every 100 plants,

- purification plants under construction every 100 existing plants,

- citizens served with a completed purification system of the urban water every 100 citizens,

- tons of wastes for separate refuse collection for 100 tons of urban wastes,

- plants of urban waste disposals every 1,000,000 citizens,

- yearly average capacity of incineration plants for 100 tons of urban wastes

- dumps for special wastes every 10,000 square kilometers.

\section{2) Energy:}

- citizens in municipalities served with methane every 100 citizens,

- kilometers of secondary network of transportation of natural gas every 100 square kilometers

- gross production of electric energy from renewable sources for 1,000 square kilometers.

\section{3) Health:}

- number of nursing auxiliary in the health institutes for each surgeon,

- number of medics every 10,000 citizens,

- utilization rate of beds in the public health institutes

- number of workers in the residential socio-assistential health point every 1,000 citizens.

\section{4) Education:}

- public elementary schools provided with meals every 100 schools,

- public elementary schools equipped with school-bus every 100 schools

- special classrooms of the public secondary schools every 100 classrooms.

5) Institutions, our fifth PA efficiency indicator, is calculated as the sum of (1) to (4). All these indicators are elaborations from ISTAT (2008) data. 


\section{Additional controls}

6) Education (average years): it is measured as the average years of schooling of the labor force, that is:

$$
\text { Average years of schooling }=\square j Y R j^{*} H K j
$$

where $j$ is the schooling level, YR $j$ is the number of years of schooling represented by level $j$, and $H K j$ is the fraction of the labour force for which the $j$ th level of education represents the highest level attained. Within the Italian system, primary school lasts eight years, the secondary level is usually attained after five years, and university courses take four to six years.

7) Social capital: it is a broad measure of social capital at regional NUTS3 level that merges data on 1) blood donations, 2) sport participation, 3) dissemination of newspaper and 4) voter turnout. From Cartocci (2007).

8) South: dummy variable equal to one if the province is located in the following NUTS(2) regions, Abruzzo, Molise, Campania, Puglia, Basilicata, Calabria, Sicilia e Sardegna. 


\section{A2. Historical (stylized) facts and the construction of the second set of instruments}

In order to clarify how our second set of instruments have been constructed, we briefly describe some historical facts that occurred in the Italian provinces between the 10th and the 17th century. Moreover, this information would also help us in defining the influence that the different historical institutions may have had in each territory.

During this long period the Italian peninsula has been characterized by a series of continuous administrative and border changes. Therefore, we need to make some simplifying assumptions in order to construct the matrix. First of all, problems arise since, in many cases, the borders of modern provinces do not perfectly correspond to those of the ancient states. We solve this issue by assigning the province to the domination that administrated the majority of its territory ${ }^{41}$. A second difficulty concerns the real power and influence exerted by the political dominator. In particular, historians suggest that many formally independent state/areas were, in fact, strongly influenced by foreign domination. Nevertheless, since the degree of foreign influence varies significantly (across periods and provinces) in this study we consider as independent also the provinces that were influenced by foreign powers. We believe this choice is the one least affected by a lack of objective criteria. To construct our matrix ${ }^{42}$ we finally identify ten main political dominations of the Italian provinces: Republic of Venice, Hapsburg-Austrian, Savoy, Papal state, the Normans, the Swabian, the Anjou, Aragonese, Bourbons, Independents. In the following we describe the different dominations starting with that located in the Northern, Centre and Southern part of Italy.

We open our brief historical appendix with the Republic of Venice. The Serenissima, as it was also known, has represented a great exception in the Italian political scenario. In fact, it has been the only state to preserve a full independence (not only de iure but also de facto) until 1797 when, with the Campoformio Treaty, it became part of the Austrian Empire. The Republic had an original form of government: it was oligarchic and the chief was the Doge. Even if this system was not democratic, it guaranteed a strong political stability that helped Venice to remain independent against the different foreign powers during these centuries. Trade (with east and Far East) represented the major source of its economic prosperity and the Republic had also different colonies in the Mediterranean Sea. Only from 1453, when Turkish conquered Constantinople, Venice began to lose its commercial power in the sea and to become more important in the Veneto and in Lombardy. If the Republic managed to preserve its territories for centuries, it was thanks to its highly efficient administration ${ }^{43}$. For these reasons, their policy should have had a positive impact on the institutional organization and we expect a positive effect.

The 16th century, instead, has been characterized, in part of the North-East, by the Hapsburg dynasty. They were in fact the foreign power that dominated Italy since 1713 after the Utrecht Treaty. With this agreement the Hapsburg conquered the Duchy of Milan, Sardinia (until 1720), the Kingdom of Naples (until 1734) and, since 1720, Sicily (until 1734 as well). In addition, their influence was also strong on Tuscany and on the Duchy of Parma and Piacenza. The Trentino, the Alto Adige and almost the whole Venezia Giulia were part of the Austrian Empire. This situation remained stable for the whole century; during this period the Empire was ruled by two important monarchs (Mary Theresa of Austria and Joseph II) and the chancellor Kaunitz, that managed to give their Empire a good administrative and bureaucratic organization in their territories including Italy. In addition, they implemented a strong and efficient judiciary system and they even attempted several economic reforms in favor of industry. In addition, it is

\footnotetext{
${ }^{41}$ We prefer this choice to the alternative used by De Blasio and Nuzzo (2009), that attributes to the entire province the characteristic (regime) that was in place in the provincial capital (in the middle ages).

42 We have to thank Pierpaolo Merlin and Giangiacomo Ortu that helped us to find historical sources and discussed with us the most plausible simplifications we had to make in order to construct our matrix. Needless to say, all errors or omissions are our full responsibility.

43 Cozzi and Knapton (1986).
} 
also considered a period of religious tolerance during which Joseph II abolished the death penalty and the feudal privileges ${ }^{44}$. In sum, the Austrian policies should have had a positive effect on local institutions. On this, see also Becker et al. (2011).

The influence played by the Savoy dynasty ${ }^{45}$ is more ambiguous. It governed in the Aosta Valley during the whole period considered but very early, at the end of the 12th century, it gradually extended its territories to include almost the whole Piedmont. It became the only state, together with Venice, to have an autonomous policy without foreign influences. These territories have seen the formation of a modern organization, similar to those of the rest of Europe, with the gradual passage from a feudal state to a modern one. In 1720 the Duchy managed to obtain the Kingdom of Sardinia with the royal title but their role in the administration of these territories is more ambiguous and it is fair to say that we can talk about a modern state (with a real eradication of feudalism form of government) only for the Northern territories. The government was characterized by a strong central power, an authoritarian bureaucracy and the fight against local nobility. Mainly during the 1700s (during the reign of Vittorio Amedeo ) we witness the rise of the middle class with an increasing role of the University of Turin in creating a class of bureaucrats. Together with these reforms, mainly concentrated on a specific area close to Turin, the Savoy kingdom has also concentrated a lot of efforts in foreign policy since territorial expansion has always represented one of the main political objectives, maybe more than development policies. For all these reasons, we expect their overall impact on the institutional organization to be ambiguous.

In the Centre of Italy, a significant role over these centuries has been played by the Papal State. The territories of the Church included Lazio, Umbria, Marche and Emilia Romagna for the most part of the period examined. The Papal state is almost unanimously considered by historians as a bad administrator. In the few occasions in which it gave evidence of good administration, it was limited on the city of Rome. In all the other territories, for the whole period, there has been a perpetual diarchy between the religious and local powers. Often, this situation resulted in anarchy ${ }^{46}$. The church and, therefore, the Government did not help improve the population educational levels the Counter-Reformation negatively influenced this area (and the Spanish dominated ones) more than other parts of the country. At the beginning of 1700, the Papal State had very few positive aspects: "Negative balance of payment, wealth drain towards foreign countries, famines, lack or failure of any commercial, manufacturing and credit activities, public debt, administrative and fiscal disorganization [...]"47. Therefore, the Papal state is expected to have had a negative influence on institutions.

In the Southern part of the country we find a more heterogeneous situation with different dominations that ruled and influenced the area during the observed period. The 12th century saw the Normans conquer the whole Mezzogiorno defeating Byzantines (in the South of Italy) and Arabians (in Sicily) under the leadership of the Altavilla family. Their purpose was to form a state that was independent from little feudatories and administrated by high quality civil servants. Especially with William II, the Normans show their respect for population and for the national laws. Even if they were good administrators, it was a very troubled period for the Kingdom of Sicily because of the continuous internal (between sovereign and feudatories) and external fights $^{48}$. Overall, due to continuous wars of the period the net effect of this otherwise good administration is therefore ambiguous.

After Normans, we find the Hoenstaufen of Swabia that conquered the control of the South of Italy in 1194 after the weddings between Henry IV and Constance of Altavilla, last descendent of the Norman family. The Swabian kept the control of the Kingdom of Sicily (including the whole Mezzogiorno) until 1266. This is identified as a positive domination,

\footnotetext{
${ }^{44}$ Montanelli and Gervaso (2003).

45 See also Merlin (1994).

46 Caravale and Caracciolo (1978).

${ }^{47}$ Caravale and Caracciolo (1978).

48 Montanelli and Gervaso (2003).
} 
especially for the role played by Frederick II, the emperor defined Stupor Mundi for his (also good administrative) qualities. His Constitution of Melfi was a new legal code for his Kingdom of Sicily and brought revolutionary changes, in particular, in reducing the influence of feudatories in his territories. His objective was to create a secular and well-ordered State and founded the University of Naples to shape a new ruling class that was able to administrate the territory and tried to stimulate the arts. In addition, he stimulated commercial links with all the Mediterranean countries. Unambiguously, we expect Swabian policies to have a positive impact on institutions.

The Mezzogiorno had to change its administration again in 1266, when the Anjou family, part of but independent from the regnant family of France, conquered the control of Southern Italy, with the help of Pope Clement IV. Their policies were based on a strong fiscal system, but also on the regular fights against local feudal nobility that sometimes resulted in continuous rebellions in Naples and in Sicily (then conquered by Spanish in 1282) ${ }^{49}$ and, therefore, in formal anarchy. In addition, the entire territory was under a strict military control that forced population to live in a sort of perpetual state of siege with virtually no freedom. The main purpose of this policy was to abolish the modern state constructed by Swabian during the previous century. The continuous wars caused a drop in agriculture productivity and a huge amount of public expenditure allocated to military expenditure. "Under the first years of Anjou domination, the Kingdom was considered unanimously as one of the biggest Southern European and Mediterranean powers. Two centuries after, it is the big and sick Kingdom placed in the middle of three seas[...]"50. With these premises, our judgment about Anjou is negative.

The Aragonese governed the South of Italy since 1442 (Sicily since 1282, Sardinia since 1420). This political situation remained stable until 1502, when all these territories went to the Spanish Crown. Since 1526 on, the Duchy of Milan too was conquered by Spain but, administrated by a governor, Milan had a wide autonomy at the bureaucratic level. The Aragonese period was relatively stable and positive period. Galasso (2005) emphasizes two policies adopted by Iberian monarchs: they built the basis for a modern absolutist state and considered their southern Italy territories as part of the Kingdom and not just a colony to exploit, while inefficiencies were probably due to the low quality of civil servants ${ }^{51}$. During the Spanish period the bureaucratic reforms continued with the same logic. The purpose was to strengthen the presence of the State in the different provinces and to guarantee the education of civil servants with the adequate administrative skills. ${ }^{52}$ However, since the second half of 16 th century we observe a change: the viceroys began to strongly repress opponents and heretics, while feudal policies negatively affected the agricultural sector. The negative effects of these new rules of the Spanish domination have particularly affected Sardinia, where a previous administration during the period of Giudicati had brought positive results. Thus, the role played by the Spanish and Aragonese is overall negative.

The successors of the Spanish domination were the Bourbon family that in 1734 started to rule over the Mezzogiorno. Artisans and merchants, the only categories that could give energy to the economic system, were absent. They inherited badly administrated territories and a critical economic situation worsened with the expulsion of the Jews, ordered by Carlo of Bourbon because of his great devotion to the Pope, that were able to guarantee a minimum of industrial activity. The Bourbon administrators tried to improve, with ambiguous results, the conditions of the City of Naples but put no or low efforts in the rest of the territories. In addition, they did not improve the educational system that Carlo Bourbon did not consider important. In sum, we do not expect a positive effect in the South of Italy of the Bourbon administration.

\footnotetext{
${ }^{49}$ During the Vespro War. In 1442 Spanish conquered all the rest of Kingdom of Naples.

50 Our translation from Galasso G. (2005).

${ }^{51}$ From Galasso (2005): "The efforts made by the Aragonese dynasty were noticeable and rich of results".

52 Galasso G. (1994).
} 


\section{A3. Instruments sets}

Table A1 - Dummy approach

\begin{tabular}{|c|c|c|c|c|c|}
\hline Province & Domination & Province & Domination & Province & Domination \\
\hline Bolzano & AUS & Rieti & PON & Brindisi & SPA \\
\hline Belluno & AUS & Latina & $\overline{P O N}$ & Matera & SPA \\
\hline Gorizia & AUS & Frosinone & PON & Potenza & SPA \\
\hline Trieste & AUS & Roma & PON & Reggio di Calabria & SPA \\
\hline Trento & IND & Cuneo & SAV & Catanzaro & SPA \\
\hline Genova & IND & Verbano-Cusio-Ossola & SAV & Cosenza & SPA \\
\hline Savona & IND & Biella & SAV & Crotone & SPA \\
\hline La Spezia & IND & Vercelli & SAV & Vibo Valentia & SPA \\
\hline Imperia & IND & Asti & SAV & Catania & SPA \\
\hline Rimini & IND & Torino & SAV & Caltanissetta & SPA \\
\hline Ravenna & IND & Aosta & SAV & Siracusa & SPA \\
\hline Modena & IND & Novara & SPA & Enna & SPA \\
\hline Reggio nell'Emilia & IND & Alessandria & SPA & Messina & SPA \\
\hline Ferrara & IND & Milano & SPA & Trapani & SPA \\
\hline Forlì-Cesena & IND & Cremona & SPA & Agrigento & SPA \\
\hline Piacenza & IND & Como & SPA & Palermo & SPA \\
\hline Parma & IND & Pavia & SPA & Ragusa & SPA \\
\hline Prato & IND & Lecco & SPA & Cagliari & SPA \\
\hline Arezzo & IND & Lodi & SPA & Nuoro & SPA \\
\hline Pistoia & IND & Varese & SPA & Oristano & SPA \\
\hline Massa-Carrara & IND & Teramo & SPA & Sassari & SPA \\
\hline Pisa & IND & Pescara & SPA & Bergamo & VEN \\
\hline Lucca & IND & L’Aquila & SPA & Sondrio & VEN \\
\hline Firenze & IND & Chieti & SPA & Mantova & VEN \\
\hline Livorno & IND & Campobasso & SPA & Brescia & VEN \\
\hline Grosseto & IND & Isernia & SPA & Vicenza & VEN \\
\hline Viterbo & PON & Napoli & SPA & Treviso & VEN \\
\hline Bologna & PON & Caserta & SPA & Rovigo & VEN \\
\hline Siena & $\mathrm{PON}$ & Benevento & SPA & Padova & VEN \\
\hline Perugia & PON & Avellino & SPA & Verona & VEN \\
\hline Terni & $\overline{\mathrm{PON}}$ & Salerno & SPA & Venezia & VEN \\
\hline Pesaro e Urbino & $\overline{P O N}$ & Bari & SPA & Pordenone & VEN \\
\hline Ancona & $\overline{\mathrm{PON}}$ & Taranto & SPA & Udine & VEN \\
\hline Ascoli Piceno & $\overline{\mathrm{PON}}$ & Lecce & SPA & & \\
\hline Macerata & $\overline{P O N}$ & Foggia & SPA & & \\
\hline
\end{tabular}

\begin{tabular}{|cccccc|}
\hline AUS & IND & PON & SAV & SPA & VEN \\
\hline Austria & Indipendent & Papal state & Savoy & Spain & Venetian \\
\hline
\end{tabular}


Table A2 - Matrix approach

\begin{tabular}{|c|c|c|c|c|c|c|c|c|c|c|}
\hline Provincia & NOR & SVE & ANG & SPA & BOR & PON & IND & VEN & AUS & SAV \\
\hline Agrigento & 94 & 72 & 36 & 411 & 66 & 0 & 0 & 0 & 14 & 7 \\
\hline Alessandria & 0 & 0 & 0 & 171 & 0 & 0 & 435 & 0 & 0 & 94 \\
\hline Ancona & 0 & 0 & 0 & 0 & 0 & 600 & 100 & 0 & 0 & 0 \\
\hline Aosta & 0 & 0 & 0 & 0 & 0 & 0 & 0 & 0 & 0 & 700 \\
\hline Arezzo & 0 & 0 & 0 & 0 & 0 & 0 & 700 & 0 & 0 & 0 \\
\hline Ascoli Piceno & 0 & 0 & 0 & 0 & 0 & 443 & 257 & 0 & 0 & 0 \\
\hline Asti & 0 & 0 & 0 & 0 & 0 & 0 & 474 & 0 & 0 & 226 \\
\hline Avellino & 114 & 52 & 176 & 271 & 66 & 0 & 0 & 0 & 21 & 0 \\
\hline Bari & 114 & 52 & 176 & 271 & 66 & 0 & 0 & 0 & 21 & 0 \\
\hline Belluno & 0 & 0 & 0 & 0 & 0 & 0 & 400 & 300 & 0 & 0 \\
\hline Benevento & 114 & 52 & 176 & 271 & 66 & 0 & 0 & 0 & 21 & 0 \\
\hline Bergamo & 0 & 0 & 0 & 0 & 0 & 0 & 328 & 372 & 0 & 0 \\
\hline Biella & 0 & 0 & 0 & 0 & 0 & 0 & 277 & 0 & 0 & 423 \\
\hline Bologna & 0 & 0 & 0 & 0 & 0 & 294 & 406 & 0 & 0 & 0 \\
\hline Bolzano/Bozen & 0 & 0 & 0 & 0 & 0 & 0 & 263 & 0 & 437 & 0 \\
\hline Brescia & 0 & 0 & 0 & 0 & 0 & 0 & 326 & 374 & 0 & 0 \\
\hline Brindisi & 114 & 52 & 176 & 271 & 66 & 0 & 0 & 0 & 21 & 0 \\
\hline Cagliari & 0 & 0 & 0 & 389 & 0 & 0 & 224 & 0 & 7 & 80 \\
\hline Caltanissetta & 94 & 72 & 36 & 411 & 66 & 0 & 0 & 0 & 14 & 7 \\
\hline Campobasso & 114 & 52 & 176 & 271 & 66 & 0 & 0 & 0 & 21 & 0 \\
\hline Caserta & 114 & 52 & 176 & 271 & 66 & 0 & 0 & 0 & 21 & 0 \\
\hline Catania & 94 & 72 & 36 & 411 & 66 & 0 & 0 & 0 & 14 & 7 \\
\hline Catanzaro & 114 & 52 & 176 & 271 & 66 & 0 & 0 & 0 & 21 & 0 \\
\hline Chieti & 114 & 52 & 176 & 271 & 66 & 0 & 0 & 0 & 21 & 0 \\
\hline Como & 0 & 150 & 0 & 173 & 0 & 0 & 290 & 0 & 87 & 0 \\
\hline Cosenza & 114 & 52 & 176 & 271 & 66 & 0 & 0 & 0 & 21 & 0 \\
\hline Cremona & 0 & 0 & 0 & 173 & 0 & 0 & 430 & 10 & 87 & 0 \\
\hline Crotone & 114 & 52 & 176 & 271 & 66 & 0 & 0 & 0 & 21 & 0 \\
\hline Cuneo & 0 & 0 & 114 & 0 & 0 & 0 & 168 & 0 & 0 & 418 \\
\hline Enna & 94 & 72 & 36 & 411 & 66 & 0 & 0 & 0 & 14 & 7 \\
\hline Ferrara & 0 & 0 & 0 & 0 & 0 & 202 & 498 & 0 & 0 & 0 \\
\hline Firenze & 0 & 0 & 0 & 0 & 0 & 0 & 700 & 0 & 0 & 0 \\
\hline Foggia & 114 & 52 & 176 & 271 & 66 & 0 & 0 & 0 & 21 & 0 \\
\hline Forlì-Cesena & 0 & 0 & 0 & 0 & 0 & 294 & 406 & 0 & 0 & 0 \\
\hline Frosinone & 0 & 0 & 0 & 0 & 0 & 700 & 0 & 0 & 0 & 0 \\
\hline Genova & 0 & 0 & 0 & 0 & 0 & 0 & 700 & 0 & 0 & 0 \\
\hline Gorizia & 0 & 0 & 0 & 0 & 0 & 0 & 400 & 0 & 300 & 0 \\
\hline Grosseto & 0 & 0 & 0 & 150 & 63 & 0 & 457 & 0 & 30 & 0 \\
\hline Imperia & 0 & 0 & 0 & 0 & 0 & 0 & 700 & 0 & 0 & 0 \\
\hline Isernia & 114 & 52 & 176 & 271 & 66 & 0 & 0 & 0 & 21 & 0 \\
\hline L`Aquila & 114 & 52 & 176 & 271 & 66 & 0 & 0 & 0 & 21 & 0 \\
\hline La Spezia & 0 & 0 & 0 & 0 & 0 & 0 & 700 & 0 & 0 & 0 \\
\hline
\end{tabular}




\begin{tabular}{|c|c|c|c|c|c|c|c|c|c|c|}
\hline Latina & 0 & 0 & 0 & 0 & 0 & 700 & 0 & 0 & 0 & 0 \\
\hline Lecce & 114 & 52 & 176 & 271 & 66 & 0 & 0 & 0 & 21 & 0 \\
\hline Lecco & 0 & 0 & 0 & 173 & 0 & 0 & 440 & 0 & 87 & 0 \\
\hline Livorno & 0 & 0 & 0 & 0 & 0 & 0 & 700 & 0 & 0 & 0 \\
\hline Lodi & 0 & 0 & 0 & 173 & 0 & 0 & 440 & 0 & 87 & 0 \\
\hline Lucca & 0 & 0 & 0 & 0 & 0 & 0 & 700 & 0 & 0 & 0 \\
\hline Macerata & 0 & 0 & 0 & 0 & 0 & 443 & 257 & 0 & 0 & 0 \\
\hline Mantova & 0 & 0 & 0 & 0 & 0 & 0 & 607 & 0 & 93 & 0 \\
\hline Massa-Carrara & 0 & 0 & 0 & 0 & 0 & 0 & 700 & 0 & 0 & 0 \\
\hline Matera & 114 & 52 & 176 & 271 & 66 & 0 & 0 & 0 & 21 & 0 \\
\hline Messina & 94 & 72 & 36 & 411 & 66 & 0 & 0 & 0 & 14 & 7 \\
\hline Milano & 0 & 0 & 0 & 173 & 0 & 0 & 440 & 0 & 87 & 0 \\
\hline Modena & 0 & 0 & 0 & 0 & 0 & 0 & 700 & 0 & 0 & 0 \\
\hline Napoli & 114 & 52 & 176 & 271 & 66 & 0 & 0 & 0 & 21 & 0 \\
\hline Novara & 0 & 0 & 0 & 173 & 0 & 0 & 440 & 0 & 25 & 62 \\
\hline Nuoro & 0 & 0 & 0 & 389 & 0 & 0 & 224 & 0 & 7 & 80 \\
\hline Oristano & 0 & 0 & 0 & 293 & 0 & 0 & 320 & 0 & 7 & 80 \\
\hline Padova & 0 & 0 & 0 & 0 & 0 & 0 & 400 & 300 & 0 & 0 \\
\hline Palermo & 94 & 72 & 36 & 411 & 66 & 0 & 0 & 0 & 14 & 7 \\
\hline Parma & 0 & 0 & 0 & 0 & 5 & 0 & 631 & 0 & 64 & 0 \\
\hline Pavia & 0 & 166 & 0 & 173 & 0 & 0 & 274 & 0 & 87 & 0 \\
\hline Perugia & 0 & 0 & 0 & 0 & 0 & 430 & 270 & 0 & 0 & 0 \\
\hline Pesaro e Urbino & 0 & 0 & 0 & 0 & 0 & 169 & 531 & 0 & 0 & 0 \\
\hline Pescara & 114 & 52 & 176 & 271 & 66 & 0 & 0 & 0 & 21 & 0 \\
\hline Piacenza & 0 & 0 & 0 & 0 & 5 & 0 & 631 & 0 & 64 & 0 \\
\hline Pisa & 0 & 0 & 0 & 0 & 0 & 0 & 700 & 0 & 0 & 0 \\
\hline Pistoia & 0 & 0 & 0 & 0 & 0 & 0 & 700 & 0 & 0 & 0 \\
\hline Pordenone & 0 & 0 & 0 & 0 & 0 & 0 & 182 & 292 & 226 & 0 \\
\hline Potenza & 114 & 52 & 176 & 271 & 66 & 0 & 0 & 0 & 21 & 0 \\
\hline Prato & 0 & 0 & 0 & 0 & 0 & 0 & 700 & 0 & 0 & 0 \\
\hline Ragusa & 94 & 72 & 36 & 411 & 66 & 0 & 0 & 0 & 14 & 7 \\
\hline Ravenna & 0 & 0 & 0 & 0 & 0 & 291 & 341 & 68 & 0 & 0 \\
\hline Reggio di Calabria & 114 & 52 & 176 & 271 & 66 & 0 & 0 & 0 & 21 & 0 \\
\hline Reggio nell`Emilia & 0 & 0 & 0 & 0 & 0 & 0 & 700 & 0 & 0 & 0 \\
\hline Rieti & 0 & 0 & 0 & 0 & 0 & 700 & 0 & 0 & 0 & 0 \\
\hline Rimini & 0 & 0 & 0 & 0 & 0 & 294 & 406 & 0 & 0 & 0 \\
\hline Roma & 0 & 0 & 0 & 0 & 0 & 700 & 0 & 0 & 0 & 0 \\
\hline Rovigo & 0 & 0 & 0 & 0 & 0 & 0 & 400 & 300 & 0 & 0 \\
\hline Salerno & 114 & 52 & 176 & 271 & 66 & 0 & 0 & 0 & 21 & 0 \\
\hline Sassari & 0 & 0 & 0 & 389 & 0 & 0 & 224 & 0 & 7 & 80 \\
\hline Savona & 0 & 0 & 0 & 0 & 0 & 0 & 700 & 0 & 0 & 0 \\
\hline Siena & 0 & 0 & 0 & 0 & 0 & 0 & 700 & 0 & 0 & 0 \\
\hline Siracusa & 94 & 72 & 36 & 411 & 66 & 0 & 0 & 0 & 14 & 7 \\
\hline Sondrio & 0 & 0 & 0 & 0 & 0 & 0 & 700 & 0 & 0 & 0 \\
\hline
\end{tabular}




\begin{tabular}{|ccccccccccc|}
\hline Taranto & 114 & 52 & 176 & 271 & 66 & 0 & 0 & 0 & 21 & 0 \\
\hline Teramo & 114 & 52 & 176 & 271 & 66 & 0 & 0 & 0 & 21 & 0 \\
\hline Terni & 0 & 0 & 0 & 0 & 0 & 602 & 98 & 0 & 0 & 0 \\
\hline Torino & 0 & 0 & 0 & 0 & 0 & 0 & 151 & 0 & 0 & 549 \\
\hline Trapani & 94 & 72 & 36 & 411 & 66 & 0 & 0 & 0 & 14 & 7 \\
\hline Trento & 0 & 0 & 0 & 0 & 0 & 0 & 700 & 0 & 0 & 0 \\
\hline Treviso & 0 & 0 & 0 & 0 & 0 & 0 & 239 & 461 & 0 & 0 \\
\hline Trieste & 0 & 0 & 0 & 0 & 0 & 0 & 282 & 0 & 418 & 0 \\
\hline Udine & 0 & 0 & 0 & 0 & 0 & 0 & 320 & 380 & 0 & 0 \\
\hline Varese & 0 & 0 & 0 & 173 & 0 & 0 & 440 & 0 & 87 & 0 \\
\hline Venezia & 0 & 0 & 0 & 0 & 0 & 0 & 0 & 700 & 0 & 0 \\
\hline Verbano-Cusio-Ossola & 0 & 166 & 0 & 173 & 0 & 0 & 274 & 0 & 87 & 0 \\
\hline Vercelli & 0 & 0 & 0 & 0 & 0 & 0 & 327 & 0 & 0 & 373 \\
\hline Verona & 0 & 0 & 0 & 0 & 0 & 0 & 400 & 300 & 0 & 0 \\
\hline Vibo Valentia & 114 & 52 & 176 & 271 & 66 & 0 & 0 & 0 & 21 & 0 \\
\hline Vicenza & 0 & 0 & 0 & 0 & 0 & 0 & 400 & 300 & 0 & 0 \\
\hline Viterbo & 0 & 0 & 0 & 0 & 0 & 700 & 0 & 0 & 0 & 0 \\
\hline
\end{tabular}




\section{Ultimi Contributi di Ricerca CRENoS}

I Paper sono disponibili in: http://www.crenos.it

11/14 Juan Gabriel Brida, Marta Meleddu, Manuela Pulina, "Museum visitors can be regarded as specific cultural tourists? A length of stay analysis"

11/13 Edoardo Otranto, "Classification of Volatility in Presence of Changes in Model Parameters"

11/12 Alessandro Fiori Maccioni, "The risk neutral valuation paradox"

11/11 Leonardo Becchetti, Vittorio Pelligra, "Don't Be Ashamed to Say You Didn't Get Much: Redistributive Effects of Information Disclosure in Donations and InequityAversion in Charitable Giving"

11/10 Alessandra Colombelli, Marta Foddi, Raffaele Paci, "The knowledge regions in the enlarged Europe"

11/09 Emanuela Marrocu, Raffaele Paci, Stefano Usai, "Proximity, Networks and Knowledge Production in Europe"

11/08 Vittorio Pelligra, "Empathy, Guilt-Aversion and Patterns of Reciprocity"

11/07 Claudio Detotto, Edoardo Otranto, "Cycles in Crime and Economy Revised"

11/06 Juan Gabriel Brida, Marta Meleddu, Manuela Pulina, "The attractiveness of a modern and contemporary art museum"

11/05 Juan Gabriel Brida, Marta Meleddu, Manuela Pulina, "An urban icon? The case of the Iceman Ötzi"

11/04 Silvia Balia, Rinaldo Brau, "A Country for Old Men? An Analysis of the Determinants of Long-Term Home Care in Europe"

11/03 Luciano Mauro, Francesco Pigliaru, "Social Capital, Institutions and Growth: Further Lessons from the Italian Regional Divide"

11/02 Juan Gabriel Brida, Claudio Detotto, Manuela Pulina, "How efficient is the Italian hospitality sector? A window DEA and truncated-Tobit analysis"

11/01 Berardino Cesi, Dimitri Paolini, "University choice, peer group and distance"

10/33 Oliviero A. Carboni, Giuseppe Medda, "A Neoclassical Growth Model with Public Spending"

10/32 Vittorio Pelligra, Luca Stanca, "To Give or Not To Give? Equity, Efficiency and Altruistic Behavior in a SurveyBased Experiment"

10/31 Emanuela Marrocu, Raffaele Paci, "Education or just Creativity: what matters most for economic performance?"

10/30 Adriana Di Liberto, Stefano Usai, TFP convergence across European regions: a comparative spatial dynamics analysis

10/29 Oliviero A. Carboni, Heterogeneity in R\&D Cooperation: An Empirical Investigation

10/28 Maurizio Conti, Giovanni Sulis, "Human Capital, Employment Protection and Growth in Europe"

10/27 Juan Gabriel Brida, Manuela Pulina, Eugenia Riaño, Sandra Zapata-Aguirre "Investigating the behavior of embarking cruisers in a Caribbean homeport: a factor and a censured-Tobit analysis" 
Finito di stampare nel mese di Settembre 2011

Presso studiografico\&stampadigitale Copy Right

Via Torre Tonda 8 - Tel. 079.200395 - Fax 079.4360444

07100 Sassari 
www.crenos.it

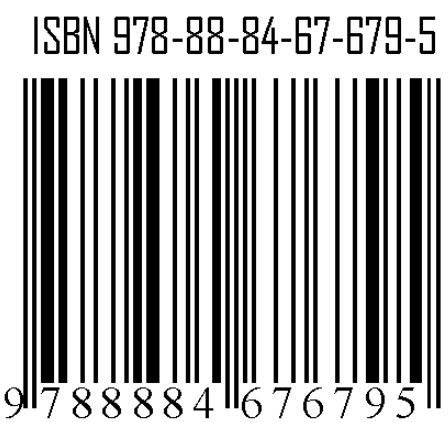

